Aus der Abteilung Kardiologie und Pneumologie

(Prof. Dr. med. G. Hasenfuß)

im Zentrum Innere Medizin

der Medizinischen Fakultät der Universität Göttingen

\title{
Nukleäre Funktionen des Muscle LIM Proteins in der Herzmuskelhypertrophie
}

\author{
I N A U G UR A L - D I S S E R T A T I O N \\ zur Erlangung des Doktorgrades \\ der Medizinischen Fakultät \\ der Georg-August-Universität zu Göttingen
}

vorgelegt von

Charlotte Donner

aus Hannover

Göttingen 2010 
Dekan:

I. Berichterstatter:

II. Berichterstatter/in:

III. Berichterstatter/in:

Tag der mündlichen Prüfung: $\quad$ 21.06.2011 


\section{Inhaltsverzeichnis}

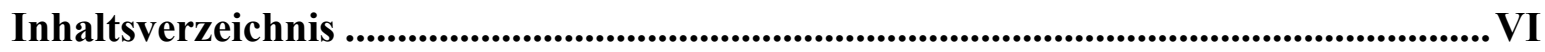

Abkürzungsverzeichnis ..................................................................................... VIII

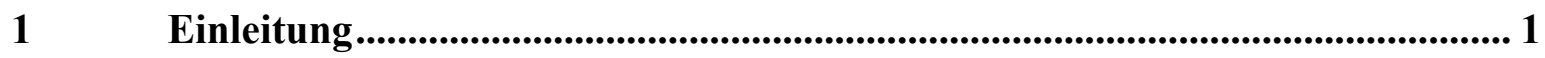

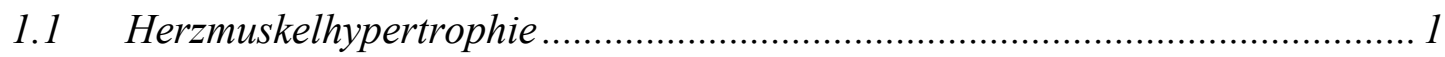

1.2 Das Muscle LIM Protein, ein LIM-only-Protein aus der CRP-Familie ............ 2

1.3 Das Muscle LIM Protein in der Herzmuskelhypertrophie................................. 4

1.4 Fragestellung der Arbeit und Vorgehensweise ................................................. 5

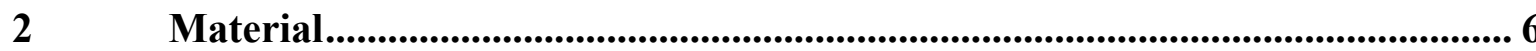

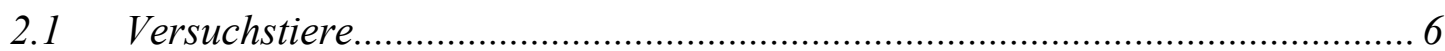

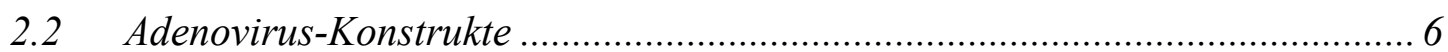

2.3 Primer für die Polymerase-Kettenreaktion ....................................................... 7

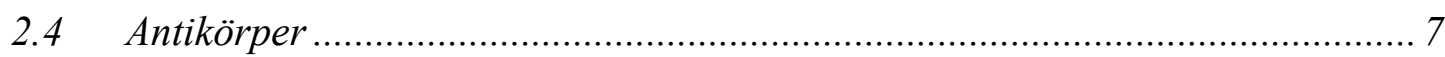

2.5 Lösungen und Substanzen ............................................................................ 7

2.5.1 Zellisolation adulte Kardiomyozyten ...................................................... 7

2.5.2 Zellisolation neonatale Kardiomyozyten .................................................. 9

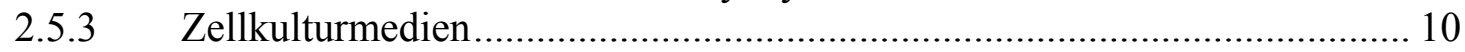

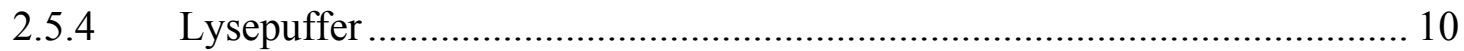

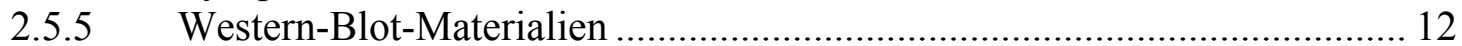

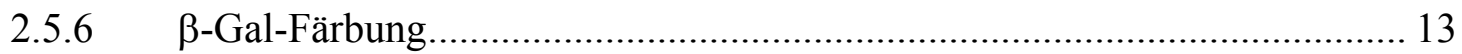

2.5.7 Verwendete Kits und Einzelsubstanzen................................................... 13

2.5.8 Verwendete Geräte..................................................................... 14

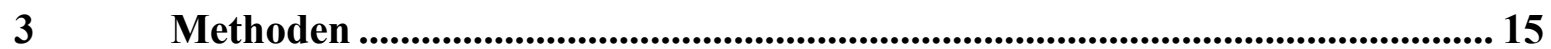

$3.1 \quad$ Koronarligatur und Sham-OP von Mäusen .................................................. 15

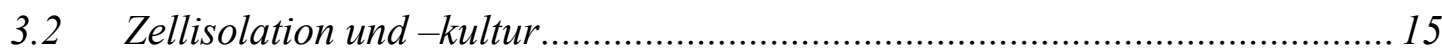

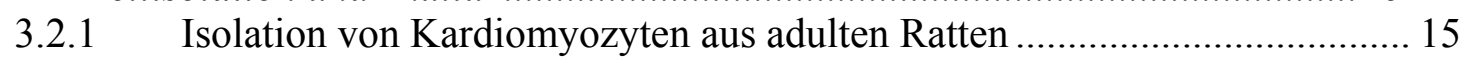

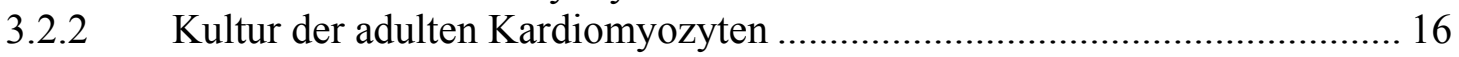

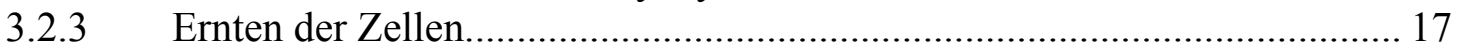

3.2.4 Isolation von Kardiomyozyten aus neonatalen Ratten............................... 17

3.2.5 Kultur der neonatalen Kardiomyozyten................................................... 18

3.2.6 Transfektion der Zellen mit Adenoviren.................................................... 19

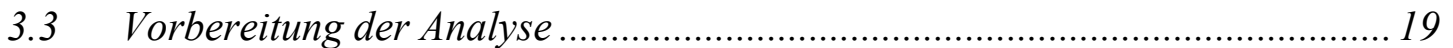

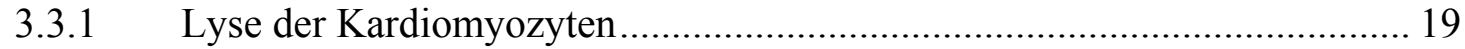

3.3.2 Herstellen von Lysaten aus Gewebeproben ............................................... 20

3.3.3 Photometrische Bestimmung der Lysate ................................................... 20

3.3.4 RNA-Isolation aus adulten Rattenmyozyten ............................................. 20

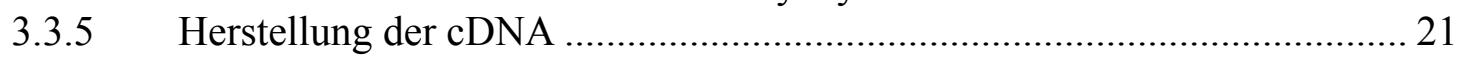




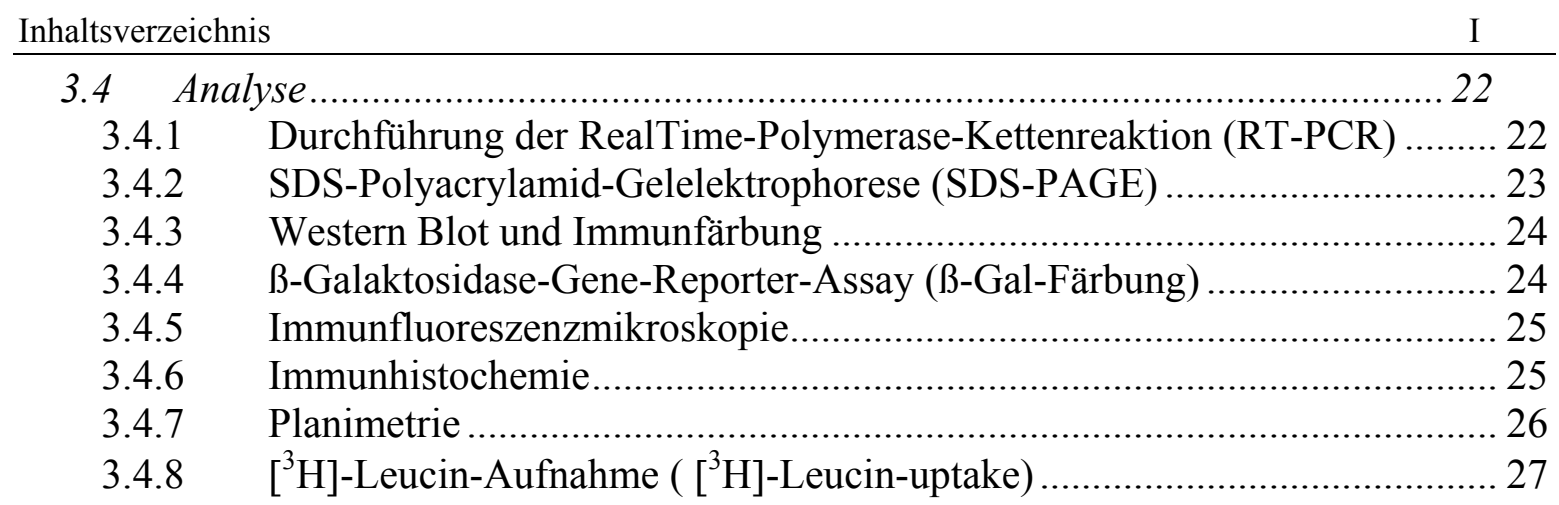

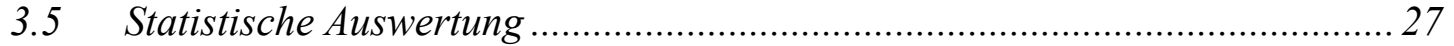

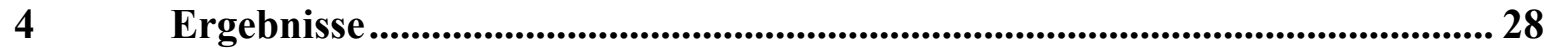

$4.1 \quad$ Nukleäre Relokalisation von MLP in Infarktherzen ..................................... 28

4.2 Expression von MLP in der Herzmuskelhypertrophie .................................. 30

4.2.1 Ausbildung von Hypertrophie-Merkmalen in den Infarktherzen ................. 30

4.2.2 Expression von MLP zwei Wochen nach Myokardinfarkt........................... 30

4.2.3 Expression von MLP drei Monate nach Infarkt.......................................... 31

$4.3 \quad$ Funktionsfähigkeit des nls-MLP-Virus ........................................................ 32

4.3.1 Bestimmung der Transfektionseffizienz .............................................. 32

4.3.2 Verifizierung der nls-MLP-Expression mittels Western Blot ..................... 33

4.3.3 Immunzytochemische Färbung zur Lokalisation des Virus......................... 35

4.4 Untersuchung von Kardiomyozyten auf Hypertrophie-Merkmale nach

Transfektion mit dem nls-MLP-Virus...................................................... 36

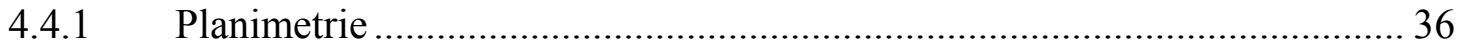

4.4.2 Analyse der Expression von ANF, BNP und $\beta$-MHC ….......................... 37

4.4.3 Autoradiographische Untersuchung auf eine veränderte Proteinsynthese anhand der Inkorporation von $\left[{ }^{3} \mathrm{H}\right]$-Leucin ........................................... 39

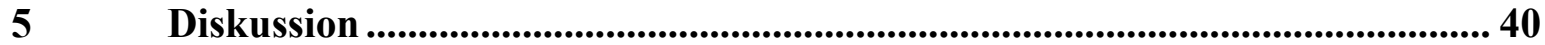

5.1 Nukleäre Relokalisation und Expression von MLP in der Herzmuskelhypertrophie ..................................................................................... 40

$5.2 \quad$ Funktion von MLP im Zellkern ............................................................. 43

5.3 Schlussfolgerung und Ausblick ..................................................................... 47

$6 \quad$ Zusammenfassung.................................................................................................. 48

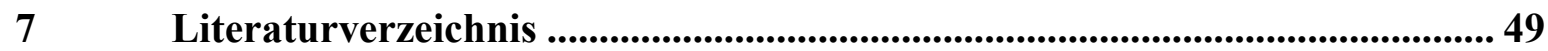




\section{Abkürzungsverzeichnis}

\begin{tabular}{|c|c|}
\hline ANP & atriales natriuretisches Peptid \\
\hline APS & Ammoniumpersulfat \\
\hline$\beta \mathrm{Gal}$ & beta-Galaktosidase \\
\hline bHLH & beta-Helix-Loop-Helix-Transkriptionsfaktoren \\
\hline$\beta \mathrm{MHC}$ & beta-Myosin heavy chain \\
\hline BNP & Brain natriuretisches Peptid \\
\hline BSA & Bovines Serumalbumin \\
\hline cDNA & komplementäre DNA \\
\hline $\mathrm{CO}_{2}$ & Kohlendioxid \\
\hline CRP & Cystein-reiches Protein \\
\hline DAB & Diaminobenzidin \\
\hline DMSO & Dimethylsulfoxid \\
\hline DNA & Desoxyribonukleinsäure \\
\hline EDTA & Ethylen-Diamin-Tetra-Essigsäure \\
\hline EGTA & Ethylenglykol-bis-(2-aminoethyl)-Tetra-Essigsäure \\
\hline ENI & European Neuroscience Institute Göttingen \\
\hline FCS & Fetales Kälberserum \\
\hline GAPDH & Glycerinaldehyd-3-phosphat-Dehydrogenase \\
\hline GATA & Transkriptionsfaktor, bindet an ((A/T)GATA(A/G)) \\
\hline HEPES & 4-(2-Hydroxyethyl)-piperazin-1-Ethanolsulfonsäure \\
\hline IE & Internationale Einheit \\
\hline LAD & $\begin{array}{l}\text { left anterior descending, entspricht dem Ramus interventricularis } \\
\text { anterior }\end{array}$ \\
\hline MyoD & $\begin{array}{l}\text { Helix-Loop-Helix-Transkriptionsfaktor, gehört zu den Myogenese } \\
\text { regulierenden Faktoren (MRFs) }\end{array}$ \\
\hline$\left[\mathrm{H}^{3}\right]-$ Leucin & $\mathrm{L}-\left[3,4,5-{ }^{3} \mathrm{H}(\mathrm{N})\right]$-Leucin \\
\hline M & Molar (mol/l) \\
\hline MI & Myokardinfarkt \\
\hline Min & Minuten \\
\hline
\end{tabular}


MLP

$\mathrm{N}$

MOI

$\mathrm{Nls}$

NO

$\mathrm{O}_{2}$

PAGE

Pfu

PMSF

RLT-Puffer

RNA

RPE-Puffer

RT-PCR

RW1-Puffer

SDS

SRF

Std

TBS

TCA

TEMED

TRIS

Tween

$\mathrm{U}$

ZTE
Muscle LIM Protein

Normal

Multiplicity of infection

Nukleäres Lokalisierungssignal

Stickoxid

Sauerstoff

Polyacrylamid-Gel-Elektrophorese

Plaque forming unit

Phenylmethansulfonyl-Fluorid

Puffer aus dem RNeasy Mini Kit (Quiagen), enthält

Guanidinisothiocyanat zur Proteindenaturierung

Ribonukleinsäure

Puffer aus dem RNeasy Mini Kit (Quiagen), genaue

Zusammensetzung nicht bekannt

RealTime-Polymerase-Kettenreaktion

Puffer aus dem RNeasy Mini Kit (Quiagen), genaue

Zusammensetzung nicht bekannt

Sodiumdodecylsulfat

Serum Response Factor

Stunden

TRIS-gepufferte Kochsalzlösung

Trichloressigsäure

$=$ TMEDA, Tetramethylethylendiamin

Tris(hydroxymethyl)-Aminomethan

Polyoxyethylensorbitan-monolaurat

Umdrehungen

Zentrale Tierexperimentelle Einrichtung, Universitätsmedizin Göttingen 


\section{$1 \quad$ Einleitung}

\subsection{Herzmuskelhypertrophie}

Hypertrophie ist definiert als Massenzunahme des Herzens durch Größenzunahme der Zellen bei gleichbleibender Zellzahl. Nach Abschluss der Herzentwicklung kommt es zu einer Hypertrophie des Herzens bei Ausdauersport, in der Schwangerschaft und auch im Rahmen vieler Herzerkrankungen. Die Hypertrophie, die als Begleiterscheinung von Herzerkrankungen auftritt, wird als ,pathologisch“ bezeichnet und von den anderen „physiologischen“ Formen der Herzmuskelhypertrophie abgegrenzt. Ischämische Herzkrankheit, Hypertonie, Herzinsuffizienz und Klappenvitien rufen eine Hypertrophie des Myokards hervor, was als Kompensationsmechanismus gewertet wird, um die Wandspannung des linken Ventrikels bei stärkerer Belastung konstant zu halten, auf lange Sicht jedoch für Herzversagen, Arrhythmien und plötzlichen Herztod prädisponiert (Clerk et al. 2007; Frey et al. 2004; Frey und Olson 2003; Heineke und Molkentin 2006). Das bessere Verständnis der molekularen Mechanismen, die der Herzmuskelhypertrophie zugrunde liegen, ist somit ein wichtiger Ansatz in der Prävention von Herzversagen, das in der westlichen Welt noch immer eine der führenden Todesursachen darstellt (Kannel 2000; Levy et al. 2002).

Die Hypertrophie wird als reaktiver Prozess auf eine vermehrte Belastung des Herzens im Sinne von Druck- oder Volumenbelastung, genetischen Mutationen bestimmter Proteine oder Verlust von intakter Muskulatur betrachtet (Frey et al. 2004). Anhand der anatomischen Phänotypen kann eine Einteilung der Hypertrophie in eine konzentrische Form mit starker Zunahme der Wanddicke und abnehmendem Ventrikelvolumen und eine exzentrische Form mit einer proportionalen Zunahme von Wanddicke und Ventrikelvolumen gemäß dem Laplace'schen Gesetz erfolgen, wobei teilweise zusätzlich eine dilatative Form unterschieden wird. Während die physiologische Hypertrophie exzentrisch ist, kann die pathologische Hypertrophie sowohl exzentrisch wie auch konzentrisch auftreten und in eine Ventrikeldilatation münden (Heineke und Molkentin 2006).

Herzmuskelhypertrophie geht mit morphologischen Veränderungen des Gewebes einher, so führt sie zu unterschiedlich stark ausgeprägter Apoptose, Nekrose und Fibrose (Frey et al. 
2004; Heineke und Molkentin 2006). Auch auf zellulärer Ebene zeigen sich typische Charakteristika. Es kommt zu Zellgrößenzunahme und veränderter Zytoskelettorganisation, aber auch zu einer erhöhten Proteinsynthese und veränderter Expression zahlreicher Gene (Clerk et al. 2007; Frey et al. 2004; Frey und Olson 2003; Hannan et al. 2003). Einige dieser Gene kodieren für Proteine, welche als Marker-Proteine der Hypertrophie angesehen werden. $\mathrm{Zu}$ diesen zählen beispielsweise der ,atrio-natriuretic factor“ ANF, „brainnatriuretic peptide“ BNP und die $\beta$-Form der „myosin heavy chain“, das $\beta$-MHC. Eine vermehrte Expression dieser Proteine wurde sowohl in Tiermodellen der Herzmuskelhypertrophie wie auch in hypertrophiertem menschlichem Myokard gefunden, und wird dementsprechend als Zeichen der Hypertrophie gewertet (Chien et al. 1991; Hunter und Chien 1999; Izumo et al. 1988). Die molekularen Mechanismen, welche die typischen Änderungen in der Zellmorphologie und Genexpression bedingen, sind nicht vollständig geklärt. Auch inwieweit die Unterteilung nach dem anatomischen Phänotyp und die Unterscheidung zwischen physiologischer und pathologischer Hypertrophie tatsächlich die molekularen Mechanismen widerspiegelt, ist bislang unklar (Dorn et al. 2003). Allerdings wurden - nicht zuletzt aufgrund der hohen klinischen Relevanz der Herzmuskelhypertrophie als prognostischem Faktor - die an ihrer Entstehung beteiligten Signalwege bereits eingehend untersucht und eine große Anzahl beteiligter Proteine beschrieben (Clerk et al. 2007; Frey und Olson 2003; Heineke und Molkentin 2006).

\subsection{Das Muscle LIM Protein, ein LIM-only-Protein aus der CRP-} Familie

Das Muscle LIM Protein (MLP) gehört zu der Gruppe der LIM-Proteine, die sich durch das Vorhandensein von mindestens einer LIM-Domäne auszeichnen (Dawid et al. 1998; Weiskirchen und Günther 2003). LIM-Domänen sind Strukturen aus zwei hintereinandergeschalteten Zink-bindenden Einheiten, den „Zink-Fingern“ (Michelsen et al. 1993). Jede Zink-bindende Einheit kann unabhängig von der anderen Bindungen zu Proteinen eingehen, wodurch LIM-Domänen vielfältige Funktionen als Vermittler einzelner Proteinbindungen oder Bindeglied großer Protein-Komplexe wahrnehmen können (Dawid et al. 1998; Rétaux und Bachy 2002). Der Name LIM leitet sich ab von den drei Proteinen Lin-11, Isl-1 und Mec-3, die für Transkriptionsfaktoren kodieren, in denen dieses Motiv zuerst entdeckt wurde (Freyd et al. 1990; Karlsson et al. 1990; Way und 
Chalfie 1988). Das LIM-Motiv ist im Laufe der Evolution hoch konserviert in Proteinen verschiedenster Organe und Spezies, was ein Zeichen für die wichtigen und vielfältigen Funktionen darstellt (Bach 2000; Sánchez-García und Rabbitts 1994). LIM-Proteine nehmen zytoplasmatisch und nukleär wesentliche Aufgaben wie die Regulation von Zellwachstum, Zytoskelettorganisation und Differenzierung wahr. Sie sind darüber hinaus auch an der Onkogenese beteiligt (Dawid et al. 1998; Sánchez-García und Rabbitts 1994; Zheng und Zhao 2007). Die LIM-Domänen sind für viele ihrer Funktionen entscheidend (Bach 2000). Wenn LIM-Domänen auch keine direkte DNA-Bindung vermitteln, nehmen LIM-Proteine über sie unter anderem entscheidenden Einfluss auf die Genregulation durch Bindung an Transkriptionsfaktoren (Bach 2000; Rétaux und Bachy 2002; Zheng und Zhao 2007).

Eine Untergruppe der LIM-Proteine bilden die sogenannten „LIM-only-Proteine“, die als funktionelle Strukturelemente ausschließlich LIM-Domänen in unterschiedlicher Anzahl aufweisen. Allgemein wird für LIM-only-Proteine und für die zu ihnen zählenden Cysteinreichen Proteine (abgekürzt CRP) angenommen, dass sie die Fähigkeit besitzen, zwischen Zytoplasma und Zellkern zu translozieren. Im Zellkern können sie die Transkription von Genen beeinflussen (Benmerah et al. 2003; Zheng und Zhao 2007). Zu den CRPs zählen widerum neben weiteren verwandten Proteinen vor allem CRP1, CRP2 sowie das Muscle LIM Protein MLP, welches auch CRP3 genannt wird (Weiskirchen und Günther 2003). MLP weist unter den CRPs die Besonderheit auf, dass es als einziges Protein dieser Proteinfamilie auch nach Abschluss der Entwicklung in Herzmuskelzellen noch konstant exprimiert wird (Weiskirchen und Günther 2003).

In Vertebraten zeigen die drei Proteine ein gewebespezifisches Expressionsmuster. CRP1 und CRP2 kommen vorwiegend in glatten Muskelzellen und Fibroblasten, aber auch vielen weiteren Organen vor, während MLP fast ausschließlich in Herz- und Skelettmuskulatur nachgewiesen wurde (Arber et al. 1994; Louis et al. 1997; Weiskirchen und Günther 2003). Innerhalb der Zellen können alle CRPs als typische Vertreter der LIM-Proteine sowohl zytoplasmatisch als auch nukleär vorliegen (Arber und Caroni 1996). Die Kolokalisation mit Aktinfilamenten im Zytoplasma und damit eine Assoziation zu Zytoskelettelementen wurde für alle drei CRPs gezeigt (Louis et al. 1997). Für MLP wurde in myogenen Zellen während der Differenzierung eine ausschließlich nukleäre Lokalisation und erst nach Abschluss der Entwicklung auch ein zytoplasmatisches Vorkommen beschrieben (Arber et al. 1994). In adulten Herzmuskelzellen ist MLP jedoch vorwiegend als ein 
zytoplasmatisches Protein bekannt. Es wurden bereits verschiedene Bindungspartner im Zytoplasma identifiziert, wie unter anderem $\beta 1$-Spektrin und Telethonin/Tcap (Arber et al. 1994; Ehler et al. 2001; Flick und Konieczny 2000; Gupta et al. 2008; Heineke et al. 2005). Die CRPs weisen untereinander eine starke strukturelle Ähnlichkeit auf. CRP1, CRP2 und MLP besitzen zwei LIM-Domänen, denen jeweils eine Glycin-reiche Region folgt. Allen gemeinsam ist auch ein potentielles Kernlokalisationssignal hinter der ersten LIM-Domäne, dessen Funktion für MLP bereits gezeigt werden konnte (Arber und Caroni 1996; Boateng et al. 2009; Weiskirchen und Günther 2003). Der Abstand zwischen beiden LIM-Domänen und die Gesamtlänge der Proteine variieren kaum, und die Glycin-reichen Regionen sowie das potentielle Kernlokalisationssignal sind von ihrer Sequenz her nahezu identisch (Arber und Caroni 1996; Weiskirchen et al. 1995).

Allen gemeinsam ist auch eine regulierende Funktion in der frühen Myogenese. CRP1 und CRP2 spielen eine maßgebliche Rolle in der Differenzierung glatter Muskelzellen. Über ihre LIM-Domänen wirken sie als Kofaktoren des Komplexes aus Serum-response-Faktor SRF und GATA-Transkriptionsfaktoren und regulieren auf diese Weise die Genexpression und Differenzierung in der frühen Myogenese (Chang et al. 2003). Auch für MLP konnte ein maßgeblicher Einfluss auf die Regulation der Myogenese im Zusammenhang mit seiner nukleären Lokalisation bereits gezeigt werden (Arber et al. 1994). Zusätzlich konnte für MLP die Interaktion mit Transkriptionsfaktoren im Zellkern und die Änderung der Transkription von Zytoskelettproteinen in Skelettmuskelzellen gezeigt werden. MLP interagiert dort mit bHLH-Transkriptionsfaktoren, speziell mit solchen der MyoD-Familie (Kong et al. 1997). In adulten Kardiomyozyten ist eine Funktion von MLP als Mechanosensor an der Z-Scheibe gezeigt worden (Knöll et al. 2002). Ein Einfluss auf die Genregulation im Zellkern von Herzmuskelzellen wurde für MLP bislang kaum untersucht.

\subsection{Das Muscle LIM Protein in der Herzmuskelhypertrophie}

Seit längerem ist bekannt, dass MLP im Herzen für die Organisation des Zytoskeletts sowie die Adaptation an mechanische Belastung eine immense Bedeutung hat. Dies zeigte sich in MLP-knockout-Mäusen, die eine dilatative Kardiomyopathie mit desorganisiertem Zytoskelett und Herzversagen entwickelten (Arber et al. 1997). Die Funktion von MLP als Mechanosensor an der Z-Scheibe ist ein weiterer Hinweis in diese Richtung (Knöll et al. 2002). Mutationen im Gen von MLP werden zudem für einige Formen der dilatativen und 
hypertroph obstruktiven Kardiomyopathie verantwortlich gemacht (Geier et al. 2003; Knöll et al. 2002; Mohapatra et al. 2003).

Ein Zusammenhang zwischen MLP und der Hypertrophie des Herzens und somit zu der Entstehung der Herzinsuffizienz wurde erstmals hergestellt, als ein nukleärer Nachweis von MLP sowie eine verminderte Expression von MLP in der Herzmuskelhypertrophie gezeigt werden konnten (Ecarnot-Laubriet et al. 2000; Zolk et al. 2000). Weitere Arbeitsgruppen hatten danach eine veränderte Expression von MLP in der Hypertrophie beschrieben, jedoch im Gegensatz zu den bisherigen Veröffentlichungen eine erhöhte Expression von MLP gefunden (Boateng et al. 2006; Wilding et al. 2005). Auch eine nukleäre Lokalisation des MLP in Kardiomyozyten konnte nach zyklischem Dehnungsstress erneut gezeigt werden (Boateng et al. 2006). Des Weiteren konnte das antihypertroph wirkende NO als ein Regulator der Expression von MLP identifiziert werden (Heineke et al. 2003). In diesen Versuchen wurde ebenfalls gezeigt, dass die Überexpression von MLP in Kardiomyozyten ausreichend ist, um eine Hypertrophie dieser Zellen hervorzurufen.

\subsection{Fragestellung der Arbeit und Vorgehensweise}

Das Muscle LIM Protein ist ein in adulten Kardiomyozyten konstant exprimiertes LIMonly-Protein, welches, wie die ihm verwandten Proteine CRP1 und CRP2, potentiell in den Zellkern translozieren und dort mit Transkriptionsfaktoren interagieren kann. MLP ist in Kardiomyozyten vorwiegend zytoplasmatisch lokalisiert. Es finden sich jedoch Hinweise auf eine nukleäre Lokalisation von MLP in der Herzmuskelhypertrophie, die eine zusätzliche Funktion von MLP in der Hypertrophie im Zellkern der Kardiomyozyten vermuten lassen. Auch seine Expression scheint in der Hypertrophie verändert zu werden. In der vorliegenden Arbeit wurde untersucht, wie sich die MLP-Expression in pathologischer Herzmuskelhypertrophie nach Infarkt verhält und ob auch nach Myokardinfarkt eine veränderte subzelluläre Lokalisation von MLP im Zellkern der Kardiomyozyten nachzuweisen ist. Ebenfalls wurde untersucht, ob MLP im Zellkern von Kardiomyozyten Einfluss auf die Genexpression nimmt und auf diese Weise eine Hypertrophie induzieren kann. Hierzu wurde ein um ein zusätzliches Kernlokalisierungssignal ergänztes MLP, das nls-MLP, mittels eines viralen Vektors überexprimiert und dessen Fähigkeit, eine Hypertrophie auszulösen, an Rattenkardiomyozyten untersucht. 


\section{$2 \quad$ Material}

\subsection{Versuchstiere}

Für die Isolation adulter Kardiomyozyten wurden etwa sechs Wochen alte 250-300 g schwere männliche Wistar-Ratten verwendet. Die Isolation neonataler Kardiomyozyten erfolgte aus 8-20 1-2 Tage alten neonatalen Ratten. Die Versuchstiere stammten aus der Zucht des European Neuroscience Institute (ENI, Göttingen). Die Tötung der Tiere zu wissenschaftlichen Zwecken wurde gemäß Tierschutzgesetz bei der Bezirksregierung Braunschweig angezeigt (Aktenzeichen T 8.02). Für die Erzeugung von Myokardinfarkten wurden weibliche Mäuse mit einem Körpergewicht von 20-25 g verwendet. Die Tiere stammten aus der Zucht der Zentralen Tierexperimentellen Eirichtung (ZTE) der Universitätsmedizin Göttingen. Die Tierversuche wurden vom Regirungspräsidium Braunschweig genehmigt (Aktenzeichen 33.452502-G-008/06, 33.45202-G-010/06).

\subsection{Adenovirus-Konstrukte}

Für die Überexpressionsversuche wurden folgende Adenovirus-Konstrukte verwendet:

- $\quad$ Das nls-MLP-Virus kodierte für ein durch ein nukleäres Lokalisierungssignal ergänztes MLP. Die cDNA-Sequenz wurde freundlicherweise von Stephen Konieczny zur Verfügung gestellt und in unserem Labor weitergehend modifiziert (Kong et al. 1997). Die MLP-Sequenz war um ein nukleäres Lokalisierungssignal (nls) simian SV 40 sowie um ein HA-tag ergänzt worden.

- $\quad$ Das flag-MLP-Virus kodierte für ein MLP mit flag-Anhang, der den Durchtritt durch die Kernporen verhindern sollte (Boateng at al. 2006). Das Virus wurde uns freundlicherweise von Ralph Knöll zur Verfügung gestellt.

- Das nls-LacZ-Virus kodierte für ein durch ein nukleäres Lokalisierungssignal ergänztes LacZ. Es war zuvor in unserem Labor konstruiert worden. 


\subsection{Primer für die Polymerase-Kettenreaktion}

Tab. 1 Primersequenzen

\begin{tabular}{|c|c|}
\hline Gen & Primer \\
\hline BNP & $\begin{array}{l}\text { Vorwärts } 5 ` \ldots \text { TCCAAGATGGCACATAGTTC....3` } \\
\text { Rückwärts } 5 ` \ldots \text { AGGATCACTTGAGAGAGGTGGT...3 }\end{array}$ \\
\hline ANF & $\begin{array}{l}\text { Vorwärts: } 5^{\prime} \ldots \text { ATGGGCTCCTTCTCCATCAC ...3' } \\
\text { Rückwärts: } 5^{\prime} \ldots \text { TCTTCGGTACCGGAAGCTG ...3' }\end{array}$ \\
\hline$\beta-\mathrm{MHC}$ & $\begin{array}{l}\text { Vorwärts: 5’... GCAGCTTATCAGGAAGGAATAC ...3' } \\
\text { Rückwärts: 5'... CTTGCGTACTCTGTCACTC ...3' }\end{array}$ \\
\hline GAPDH & $\begin{array}{l}\text { Vorwärts 5'... CCTTCATTGACCTCAACTAC ...3' } \\
\text { Rückwärts 5'... GGAAGGCCATGCCAGTGAGC ...3' }\end{array}$ \\
\hline
\end{tabular}

\subsection{Antikörper}

Zum immunologischen Nachweis des nukleären durch das nls-MLP-Virus überexprimierten MLP wurde ein monoklonaler Maus-Antikörper (Cell-Signaling, \#2367) verwendet. Dieser war gegen das HA-tag des überexprimierten nls-MLP gerichtet. Zur Immundetektion des Gesamt-MLP wurde ein polyklonaler Rattenantikörper (ProteinTech) verwendet.

Die Zweitantikörper für den Western Blot waren zum einen der Anti-Maus IgG vom Schaf (Amersham Bioscience) sowie der Anti-Ratte IgG vom Schaf (Amersham Bioscience).

\subsection{Lösungen und Substanzen}

\subsubsection{Zellisolation adulte Kardiomyozyten}

Alle Lösungen wurden mit $\mathrm{ddH}_{2} \mathrm{O}$ bis zur Endmenge aufgefüllt. Die pH-Werte wurden jeweils am selben Tag bei Raumtemperatur mit $\mathrm{NaOH}$ auf 7,5-7,55 eingestellt. Mit Ausnahme der 10x Tyrode-Stammlösung wurden alle Lösungen am Versuchstag frisch angesetzt.

Tab. 2 Zusammensetzung der 10x Tyrode-Stammlösung

\begin{tabular}{|l|l|l|}
\hline Substanz & Endkonzentration & Firma \\
\hline $\mathrm{NaCl}$ & $1.37 \mathrm{M}$ & Merck \\
\hline
\end{tabular}




\begin{tabular}{|l|l|l|}
\hline \hline $\mathrm{KCl}$ & $54 \mathrm{mM}$ & Merck \\
\hline $\mathrm{MgSO}_{4} \times 7 \mathrm{H}_{2} \mathrm{O}$ & $12 \mathrm{mM}$ & Merck \\
\hline $\mathrm{Na}_{2} \mathrm{HPO}_{4} \times 12 \mathrm{H}_{2} \mathrm{O}$ & $12 \mathrm{mM}$ & Merck \\
\hline HEPES & $200 \mathrm{mM}$ & Merck \\
\hline
\end{tabular}

Tab. 3 Zusammensetzung der 1x Tyrode ohne Calcium

\begin{tabular}{|l|l|l|}
\hline Substanz & Endkonzentration & Firma \\
\hline 10x Tyrode/ddH ${ }_{2} \mathrm{O}$ & $1: 4$ & - \\
\hline D-Glucose & $14,98 \mathrm{mM}$ & Merck \\
\hline $\begin{array}{l}\text { 100x Penicillin/ } \\
\text { Streptomycin }\end{array}$ & $1: 200$ & Sigma \\
\hline
\end{tabular}

Für die Calcium-haltige 1x Tyrode wurden 500ml dieser 1x Tyrode mit $500 \mu 11 \mathrm{M} \mathrm{CaCl}_{2}$ (Sigma) versetzt. Die Endkonzentration betrug $1 \mathrm{mM}$.

Tab. 4 Zusammensetzung der Verdaulösung

\begin{tabular}{|l|l|l|}
\hline Substanz & Endkonzentration & Firma \\
\hline 1x Tyrode & $1 \mathrm{x}$ & - \\
\hline $\begin{array}{l}\text { Kollagenase Typ CLS } \\
\mathrm{II}, 297 \mathrm{U} / \mathrm{mg}\end{array}$ & $1,4 \mathrm{~g} / 1$ & Biochrom \\
\hline Protease $5,2 \mathrm{U} / \mathrm{mg}$ & $0,1 \mathrm{~g} / 1$ & \\
\hline $\mathrm{CaCl}_{2}$ & $0,1 \mathrm{mM}$ & Sigma \\
\hline
\end{tabular}

Tab. 5 Calcium-Aufbau-Lösungen

\begin{tabular}{|l|l|}
\hline Lösung & Endkonzentration \\
\hline Röhrchen 1 & $0,125 \mathrm{mM}$ \\
\hline Röhrchen 2 & $0,25 \mathrm{mM}$ \\
\hline Röhrchen 3 & $0,5 \mathrm{mM}$ \\
\hline Röhrchen 4 & $1 \mathrm{mM}$ \\
\hline
\end{tabular}

Jeweils $25 \mathrm{ml}$ Calcium-freie Tyrode wurden in vier 50 -ml-Röhrchen pipettiert und mit unterschiedlichen Mengen $1 \mathrm{M} \mathrm{CaCl}_{2}$ (Sigma) versetzt. 
Tab. 6 Stop-Lösung: Medium 199 mit Zusätzen und Albumin

\begin{tabular}{|l|l|l|}
\hline Substanz & Endkonzentration & Firma \\
\hline M199 & $1 \mathrm{x}$ & Sigma \\
\hline D,L-Taurine & $5 \mathrm{M}$ & Sigma \\
\hline D,L-Carnitine & $6,2 \mathrm{mM}$ & Sigma \\
\hline $\begin{array}{l}\text { 100x Penicillin/ } \\
\text { Streptomycin }\end{array}$ & $1: 100$ & Sigma \\
\hline 100x L-Glutamin & $1: 100$ & Sigma \\
\hline Albumin Fraktion V & $0,9 \mathrm{mM}$ & $\begin{array}{l}\text { New Engl. } \\
\text { Bio Labs }\end{array}$ \\
\hline
\end{tabular}

Das Medium wurde steril filtriert, je $35 \mathrm{ml}$ in 50-ml-Röhrchen pipettiert und diese bei $-20^{\circ} \mathrm{C}$ gelagert.

\subsubsection{Zellisolation neonatale Kardiomyozyten}

Tab. 7 Verdaulösung

\begin{tabular}{|l|l|l|}
\hline Substanz & Endkonzentration & Firma \\
\hline PBS ohne $\mathrm{Ca}^{2+}, \mathrm{Mg}^{2+}$ & $1 \mathrm{x}$ & Invitrogen \\
\hline Trypsin & $5,4 \mathrm{mM}$ & Biochrom \\
\hline $\begin{array}{l}\text { Kollagenase, } \\
297 \mathrm{U} / \mathrm{mg}\end{array}$ & $25 \mu \mathrm{M}$ & Worthington \\
\hline
\end{tabular}

Tab. 8 Medium der neonatalen Kardiomyozyten während der Isolation und bei Ausplattieren

\begin{tabular}{|l|l|l|}
\hline Substanz & Endkonzentration & Firma \\
\hline DMEM:F12 Penicillin/ & $1: 1$ & Invitrogen \\
\hline $\begin{array}{l}\text { 100x } \\
\text { Streptomycin }\end{array}$ & Sigma \\
\hline FCS inaktiviert & $10 \%$ & Sigma \\
\hline
\end{tabular}

Bei Ausplattieren der Zellen wurde obiges Medium gemischt mit serumfreien 4:1 Medium (s.u.), sodass sich eine Endkonzentration von ca. 2 \% FCS ergab. 


\subsubsection{Zellkulturmedien}

Tab. 9 Medium M199 mit Zusätzen für adulte Kardiomyozyten

\begin{tabular}{|l|l|l|}
\hline Substanz & Endkonzentration & Firma \\
\hline M199 & $1 \mathrm{x}$ & Sigma \\
\hline D,L-Taurine & $5 \mathrm{M}$ & Sigma \\
\hline D,L-Carnitine & $6,2 \mathrm{mM}$ & Sigma \\
\hline Creatine Penicillin/ & $50 \mu \mathrm{l} / \mathrm{ml}$ & Sigma \\
\hline $\begin{array}{l}\text { 100x Streptomycin } \\
\text { 100x L-Glutamin }\end{array}$ & $50 \mu \mathrm{l} / \mathrm{ml}$ & Sigma \\
\hline
\end{tabular}

Tab. 10 Serumfreies 4:1(DMEM/M199)-Medium für die Kultur der neonatalen Kardiomyozyten

\begin{tabular}{|l|l|l|}
\hline Substanz & Endkonzentration & Firma \\
\hline DMEM/ M199 & $4: 1$ & $\begin{array}{l}\text { Invitrogen/ } \\
\text { Sigma }\end{array}$ \\
\hline $\begin{array}{l}\text { 100x Penicillin/ } \\
\text { Streptomycin }\end{array}$ & $5 \mu \mathrm{l} / \mathrm{ml}$ & Sigma \\
\hline
\end{tabular}

\subsubsection{Lysepuffer}

Alle Lysepuffer wurden mit $\mathrm{ddH}_{2} \mathrm{O}$ bis zur Endmenge aufgefüllt.

Tab. 11 Lysepuffer für Gewebeproben

\begin{tabular}{|l|l|l|}
\hline Substanz & Endkonzentration & Firma \\
\hline $\begin{array}{l}\mathrm{NP} 40 \\
\text { (EPEGAL CA-630) }\end{array}$ & $1 \%$ & Sigma \\
\hline Glycerol & $10 \%$ & Sigma \\
\hline $\mathrm{NaCl}$ & $137 \mathrm{mM}$ & Fluka \\
\hline Tris-HCl $\mathrm{pH}=7,4$ & $20 \mathrm{mM}$ & Paesel-Lorei \\
\hline $\mathrm{NaF}$ & $20 \mathrm{mM}$ & Sigma \\
\hline
\end{tabular}




\begin{tabular}{|l|l|l|}
\hline \hline Sodium Orthovanadat & $1 \mathrm{mM}$ & Sigma \\
\hline Sodium Pyrophosphat & $1 \mathrm{mM}$ & Sigma \\
\hline B-Glycerophosphat & $50 \mathrm{mM}$ & Sigma \\
\hline EDTA $\mathrm{pH}=8,0$ & $10 \mathrm{mM}$ & Sigma \\
\hline EGTA $\mathrm{pH}=7,0$ & $1 \mathrm{mM}$ & Sigma \\
\hline Aprotinin & $4 \mu \mathrm{g} / \mathrm{ml}$ & $\begin{array}{l}\text { Boehringer } \\
\text { Ingelheim }\end{array}$ \\
\hline Leupeptin & $4 \mu \mathrm{g} / \mathrm{ml}$ & Sigma \\
\hline Pepstatin A & $4 \mu \mathrm{g} / \mathrm{ml}$ & Sigma \\
\hline PMSF & $1 \mathrm{mM}$ & Sigma \\
\hline
\end{tabular}

Tab. 12 Lysepuffer 1 für Kardiomyozyten

\begin{tabular}{|l|l|l|}
\hline Substanz & Endkonzentration & \\
\hline Tris (Base) & $10 \mathrm{mM}$ & Paesel-Lorei \\
\hline $\mathrm{NaCl}$ & $140 \mathrm{mM}$ & Fluka \\
\hline Triton $\mathrm{X}$ & $1 \mathrm{mg} / \mathrm{ml}$ & Sigma \\
\hline
\end{tabular}

Tab. 13 Lysepuffer 2 für Kardiomyozyten

\begin{tabular}{|l|l|l|}
\hline Substanz & Endkonzentration & Firma \\
\hline Lysepuffer 1 & $1 \mathrm{x}$ & - \\
\hline $\begin{array}{l}500 \mathrm{mM} \mathrm{PMSF} \mathrm{in} \\
\text { DMSO }\end{array}$ & $1 \mathrm{mM}$ & Sigma \\
\hline Leupeptin & $20 \mu \mathrm{g} / \mathrm{ml}$ & Sigma \\
\hline $\begin{array}{l}\text { Pepstatin A } \\
\text { (in Methanol) }\end{array}$ & $0,5 \mu \mathrm{g} / \mathrm{ml}$ & Sigma \\
\hline Aprotinin & $10 \mu \mathrm{g} / \mathrm{ml}$ & $\begin{array}{l}\text { Boehringer } \\
\text { Ingelheim }\end{array}$ \\
\hline
\end{tabular}

Der Lysepuffer 2 wurde direkt vor der Lyse frisch angesetzt. 
Tab. 14 Zusammensetzung des RIPA-Lysepuffer für den [H $\left.{ }^{3}\right]$-Leucin-uptake

\begin{tabular}{|l|l|l|}
\hline Substanz & Endkonzentration & Firma \\
\hline $\begin{array}{l}\mathrm{NaCl}, 1370 \mathrm{mM} \text { in } \\
\mathrm{H}_{2} \mathrm{O}\end{array}$ & $150 \mathrm{mmol} / \mathrm{l}$ & Merck \\
\hline Tris, $200 \mathrm{mM}$ & $50 \mathrm{mM}$ & Merck \\
\hline $\mathrm{SDS} 0,1 \%$ in $\mathrm{H}_{2} \mathrm{O}$ & $0,5 \%$ & Sigma \\
\hline Nonidet $\mathrm{P} 40$ & $1 \%$ & Sigma \\
\hline $\begin{array}{l}\text { Sodium deoxycholate, } \\
10 \% \text { in } \mathrm{H}_{2} \mathrm{O}\end{array}$ & $0,1 \%$ & Sigma \\
\hline
\end{tabular}

Der $\mathrm{pH}-$ Wert wurde anschließend durch Zugabe von $\mathrm{HCl}$ auf 8,0 eingestellt.

\subsubsection{Western-Blot-Materialien}

Tab. 15 Gelzusammensetzungen

\begin{tabular}{|l|l|l|l|}
\hline Substanzen & $\begin{array}{l}\text { Trenngel 12,5 \%ig, } \\
\mathbf{1 5} \mathbf{~ m l}\end{array}$ & $\begin{array}{l}\text { Sammelgel 4 \%ig, } \\
\mathbf{5} \mathbf{~ m l}\end{array}$ & Firma \\
\hline $30 \%$ Acrylamid & $6,25 \mathrm{ml}$ & $670 \mu \mathrm{l}$ & Baack \\
\hline $4 \mathrm{x}$ Tris/SDS, $\mathrm{pH}=8,8$ & $3,75 \mathrm{ml}$ & - & $\begin{array}{l}\text { Merck } \\
\text { Sigma }\end{array}$ \\
\hline $4 \mathrm{x}$ Tris/SDS, $\mathrm{pH}=6,8$ & - & $1,25 \mathrm{ml}$ & $\begin{array}{l}\text { Merck } \\
\text { Sigma }\end{array}$ \\
\hline $10 \%$ APS & & $30 \mu \mathrm{l}$ & Sigma \\
\hline $\mathrm{TEMED}$ & $50 \mu \mathrm{l}$ & $10 \mu \mathrm{l}$ & Thermo Sci. \\
\hline $\mathrm{ddH}_{2} \mathrm{O}$ & $10 \mu \mathrm{l}$ & $3,08 \mathrm{ml}$ & - \\
\hline
\end{tabular}

Tab. 16 Pufferzusammensetzung

\begin{tabular}{|l|l|l|l|}
\hline Substanz & $\begin{array}{l}\text { Für 2 I } \\
\mathbf{5 x} \text { Transferpuffer }\end{array}$ & $\begin{array}{l}\text { Für 2 l } \\
\mathbf{5 x} \text { Laufpuffer }\end{array}$ & Firma \\
\hline Tris (Base) & $39,4 \mathrm{~g}$ & $30,2 \mathrm{~g}$ & Merck \\
\hline Glycine & $144 \mathrm{~g}$ & $144 \mathrm{~g}$ & Roth \\
\hline SDS & - & $10 \mathrm{~g}$ & Sigma \\
\hline
\end{tabular}

Der pH-Wert wurde jeweils auf 8,3 eingestellt. Für 1x Transferpuffer wurden $400 \mathrm{ml}$ 5x Transferpuffer und $400 \mathrm{ml}$ Methanol (Merck) mit $2 \mathrm{ml} 10 \%$ igem SDS versetzt und mit 
$\mathrm{ddH}_{2} \mathrm{O}$ bis 2,0 1 aufgefüllt. Für 1x Laufpuffer wurden $400 \mathrm{ml} \mathrm{5x}$ Laufpuffer mit dd $\mathrm{H}_{2} \mathrm{O}$ bis 2,0 1 aufgefüllt.

\subsection{6 $\beta$-Gal-Färbung}

Tab. 17 Zusammensetzung der $\beta$-Galaktosidase-Färbung

\begin{tabular}{|l|l|l|}
\hline Substanz & Endkonzentration & Firma \\
\hline Potassium ferrocyanat & $5 \mathrm{mM}$ & Sigma \\
\hline Potassium ferricyanat & $5 \mathrm{mM}$ & Sigma \\
\hline X-Gal & $20 \mu \mathrm{g} / \mathrm{ml}$ & Sigma \\
\hline PBS & - & Invitrogen \\
\hline
\end{tabular}

\subsubsection{Verwendete Kits und Einzelsubstanzen}

Tab. 18 Firmenangaben zu den Einzelsubstanzen und Kits

\begin{tabular}{|l|l|}
\hline Chemiluminescent Substrate & Thermo Scientific, Rockford, USA \\
\hline Entellan & Merck, Darmstadt, Deutschland \\
\hline HCl, rauchend, 37\%ig & Merck, Darmstadt, Deutschland \\
\hline Heparin-Na & Ratiopharm, Ulm, Deutschland \\
\hline Glutaraldehyd (1,5-Pentandial, Glutaral) & Baack, Schwerin, Deutschland \\
\hline iScript cDNA Synthese Kit & Biorad, München, Deutschland \\
\hline Isofluran & Baxter, Deerfield, USA \\
\hline [H ${ }^{3}$ ]Leucin, 173 Ci/mmol & Perkin Elmer, Waltham, USA \\
\hline Laminin, Maus & Biosciences, California, USA \\
\hline PBS Gibco & Invitrogen, Karlsruhe, Deutschland \\
\hline Ponceau-Rot & Sigma-Aldrich, München, Deutschland \\
\hline RNeasy Mini Kit & Quiagen, Hilden, Deutschland \\
\hline Szintillationsuniversalcocktail & Rotiszint eco plus, Carl Roth \\
\hline TBS tween & Cell Signaling, Danvers, USA \\
\hline Tris-Puffer & Bio-Rad, München, Deutschland \\
\hline Triton-X-100 (Octoxinol-9) & Bio-Rad, München, Deutschland \\
\hline Vecta Shield Mounting Medium & Vector Laboratories, Burlingame, USA \\
\hline Zymed Detektionskit, Super Picture & Invitrogen, Karlsruhe, Deutschland \\
\hline HRP Polymer Conjugate (DABmouse) & \\
\hline
\end{tabular}




\subsubsection{Verwendete Geräte}

Tab. 19 Firmenangaben zu den verwendeten Geräten

\begin{tabular}{|l|l|}
\hline Beatmungsgerät Harvard Mini Vent & $\begin{array}{l}\text { Föhr Medical Instruments, Seeheim- } \\
\text { Ober Beerbach, Deutschland }\end{array}$ \\
\hline CO $_{2}$-Inkubator, Heraeus & Sanyo, München, Deutschland \\
\hline Fluoreszenzmikroskop & Zeiss, Jena, Deutschland \\
\hline Heizplatte RCT basic & IKA, Staufen, Deutschland \\
\hline Heizspirale, U3 & Julabo, Seelbach, Deuschland \\
\hline Lichtmikroskop, CK 40 & Olympus, Hamburg, Deutschland \\
\hline Light Cycler & Roche, Mannheim, Deutschland \\
\hline Pumpe Masterflex Console drive & Cole-Parmer, Vernon Hills, USA \\
\hline Power Pac HC & Bio-Rad, München, Deutschland \\
\hline Szintillationszähler Wallac 1409 & Pegasus Scientific, Rockville, USA \\
\hline Zentrifuge 5810 R & Eppendorf, Hamburg \\
\hline
\end{tabular}




\section{$3 \quad$ Methoden}

\subsection{Koronarligatur und Sham-OP von Mäusen}

Der Myokardinfarkt wurde durch eine Ligatur um die linke Koronararterie hervorgerufen (Michael et al. 1995). Zur Vorbereitung der Operation wurde die Maus in einem Gefäß mit Isofluran narkotisiert und endotracheal intubiert. Über ein Beatmungsgerät wurden die Tiere mit einer Atmungsfrequenz von etwa 150/min und einem Atemzugvolumen von etwa $150 \mu 1$ mit einem Gemisch aus Sauerstoff und etwa 2\% Isofluran zur Aufrechterhaltung der Narkose beatmet.

Das Herz wurde durch eine linkslaterale Thorakotomie dargestellt. Anschließend wurde die linke absteigende Herzkranzarterie (LAD) unmittelbar nach dem Hervortreten unter dem linken Herzohr mit einer 9-0-Naht umstochen und ligiert. Nach der Ligatur wurde die Thoraxwand mit Einzelknopfnähten und die Haut in einer zweiten Schicht verschlossen. Die Sham-Operation erfolgte nach dem gleichen Protokoll ohne Ligatur der Koronarligatur.

\subsection{Zellisolation und-kultur}

\subsubsection{Isolation von Kardiomyozyten aus adulten Ratten}

Die Isolation der Kardiomyozyten erfolgte mittels retrograder Langendorff-Perfusion des Herzens und nachfolgendem enzymatischem Verdau. Vor Beginn der Isolation wurden die Verdaulösung, die calciumfreie und calciumhaltige Tyrode-Lösungen sowie die aufsteigend konzentrierten Calcium-Aufbau-Lösungen angesetzt.

Vor der Präparation des Herzens wurden die Tiere mit Isofluran in einem luftdicht abgeschlossenen Behälter betäubt, danach erfolgte die Tötung durch Genickbruch. Sofort nach der Tötung wurde ein Bauchschnitt gemacht und das Zwerchfell dicht an der Thoraxwand durchtrennt. Die Rippen wurden rechts und links in der Axillarlinie durchtrennt und die Thoraxwand aufgeklappt. Nun wurden 5 IE Heparin in das linke Herzohr gespritzt. Das so freigelegte Herz wurde mit einer stumpfen Pinzette gegriffen und an der Aorta ascendens abgetrennt, ebenso wurde der Truncus pulmonalis, die Pulmonalvenen sowie die Hohlvenen durchtrennt. Das Herz wurde sofort in eisgekühlte calciumhaltige Tyrode-Lösung überführt. 
Das Herz wurde nun für die nachfolgende Perfusion an einer Kanüle befestigt. Diese wurde hierzu durch die Aortenwurzel in den linken Ventrikel geführt und mit einem Faden und einer Klemme doppelt gesichert. Mit Hilfe einer Pumpe wurde ein konstanter Fluss der Perfusionslösungen durch die Kanüle gesichert. Die Perfusion begann mit calciumhaltiger Tyrode-Lösung bei $37^{\circ} \mathrm{C}$ und einer Durchflussrate von $10 \mathrm{ml} / \mathrm{min}$, solange bis das Herz mit einer regelmäßigen Frequenz schlug. Die Temperatur des Herzens und der Lösungen wurde von nun an konstant bei $37^{\circ} \mathrm{C}$ gehalten.

Sobald sich eine stabile Frequenz und Kontraktionsstärke zeigte, wurde auf calciumfreie Tyrode umgestellt und für $20 \mathrm{~min}$. bei einer Flussrate von $15 \mathrm{ml} / \mathrm{min}$ perfundiert.

Jetzt wurde mit dem enzymatischen Verdau begonnen. Die Durchflussrate wurde vermindert auf etwa $3 \mathrm{ml} / \mathrm{min}$ und aufrechterhalten, bis sich das Herz beim Anfassen mit sterilen Handschuhen weich anfühlte. Dies erforderte 15 bis 20 min. Perfusion mit der Verdau-Lösung. Nach Abtrennen von der Kanüle wurde das Herz mechanisch zerkleinert und danach in $40 \mathrm{ml}$ der Enzymlösung für $20 \mathrm{~min}$. bei $200 \mathrm{U} / \mathrm{min}$ und $37^{\circ} \mathrm{C}$ weiter verdaut. Anschließend wurde die Zellsuspension durch einen Nylonfilter in ein 50 ml-Röhrchen filtriert.

Nun erfolgten vier Sedimentationsschritte von je 10 min. in zuvor $\mathrm{O}_{2}$-begasten, $37^{\circ} \mathrm{C}$ warmen Calcium-Lösungen mit ansteigender Konzentration bis $1 \mathrm{mM}$. Nach jedem Schritt wurde der Überstand abgesaugt und verworfen.

In den Sedimentationszeiten wurden die Zellkulturschälchen laminiert. Für $35 \mathrm{~mm}$ Schälchen wurde $1 \mathrm{ml}$ Medium mit $10 \mu \mathrm{L}$ Laminin versetzt, für $100 \mathrm{~mm}$ Schälchen wurden $30 \mu$ Laminin zu 3 ml M199-Medium gegeben. Die Schälchen wurden mindestens 30 min. bei $37^{\circ} \mathrm{C}$ inkubiert. Nach dem Calcium-Aufbau auf $1 \mathrm{mM}$ wurden die Kardiomyozyten in Albumin-versetztes M199-Medium überführt und sorgfältig gemischt. Wiederum nach Sedimentation wurde der Überstand bis auf $15 \mathrm{ml}$ abgesaugt. Zum Auszählen wurden $20 \mu 1$ Zellsuspension mit $60 \mu 1$ M199-Medium verdünnt und in einer Neubauer-Zählkammer ausgezählt. Die Konzentration lag im Durchschnitt bei 2-3 x 105 Zellen / ml.

\subsubsection{Kultur der adulten Kardiomyozyten}

Direkt nach der Isolation wurden die adulten Zellen gemäß unten stehendem Schema in M199-Medium ausplattiert und mit den Adenoviren transfiziert. Nach 3 Std. wurde das Medium abgesaugt und $10 \mathrm{ml}$ neues virusfreies M199-Medium zugegeben. Die Schälchen 
wurden für 24 bis $48 \mathrm{Std}$. bei $37^{\circ} \mathrm{C}$ in einem Wasserdampf-gesättigten Inkubator mit $5 \%$ $\mathrm{CO}_{2}$-Begasung inkubiert und danach geerntet.

Tab.21 Angaben zur Zellkultur der adulten Kardiomyozyten

\begin{tabular}{|l|l|l|}
\hline Verwendung & $\begin{array}{l}\text { Menge Menge } \\
\text { Meng } \\
\text { Zellzahl/Volumen }\end{array}$ & Schälchen-Durchmesser \\
\hline Proteingewinnung & $5 \times 10^{5} / 5 \mathrm{ml}$ & $100 \mathrm{~mm}$ \\
\hline RNA-Isolation & $5 \times 10^{5} / 5 \mathrm{ml}$ & $100 \mathrm{~mm}$ \\
\hline$\beta$-Gal-Färbung & $15 \times 10^{4} / 3 \mathrm{ml}$ & $35 \mathrm{~mm}$ \\
\hline
\end{tabular}

\subsubsection{Ernten der Zellen}

Nach 24 Stunden Kultur wurde das Medium abgesaugt und die Zellen einmal mit $10 \mathrm{ml}$ Phosphat-gepufferter Kochsalzlösung (PBS) gewaschen. Danach wurden die Zellen in $3 \mathrm{ml}$ PBS mit einem Zellschaber geerntet und in 15-ml-Röhrchen überführt. Die Röhrchen wurden nun $5 \mathrm{~min}$. bei $4^{\circ} \mathrm{C}$ und $500 \mathrm{U} / \mathrm{min}$ zentrifugiert. Der Überstand wurde abgesaugt und die Pellets in flüssigem Stickstoff eingefroren. Die Lagerung erfolgte bei $-80^{\circ} \mathrm{C}$.

\subsubsection{Isolation von Kardiomyozyten aus neonatalen Ratten}

Die Lieferung der Ratten erfolgte 1- bis 2 Tage nach Geburt durch das ENI. Vor Beginn der Präparation wurden die Medien und die Verdaulösung angesetzt und auf $37^{\circ} \mathrm{C}$ erwärmt. Die Präparation wurde mit der Tötung der neonatalen Ratten durch Dekapitation mit einer desinfizierten Schere begonnen. Dann folgte ein Bauchschnitt und die Durchtrennung der Rippen in Richtung rechter und linker Axilla. Nach dem Aufklappen des Thorax wurde das Herz mit einer anatomischen Pinzette gefasst und mit der Schere unterhalb der Vorhofebene abgetrennt. Die Herzen wurden sofort in Phosphat-gepufferte Kochsalzlösung (PBS) gegeben. Nach sorgfältiger Nachresektion überschüssigen Gewebes folgte die mechanische Zerkleinerung der Herzen in der Verdaulösung und anschließend der weitere enzymatische Verdau. Die Herzen wurden hierfür zusammen mit der Verdaulösung, die Trypsin und Kollagenase enthielt, in einem Erlenmeyerkolben auf eine auf $37^{\circ} \mathrm{C}$ vorgeheizte Heizplatte gestellt und mit einem Magnetrührer bei $180 \mathrm{U} / \mathrm{min}$ für $10 \mathrm{~min}$. inkubiert. Der Überstand wurde abgesaugt und verworfen. Anschließend folgten 4 bis 5 
identische Verdauschritte in der Verdaulösung: Nach jeweils 12 bis 20 Minuten Inkubation (je nach Anzahl der Tiere) wurde der Überstand abgenommen und in ein neues Röhrchen mit $35 \mathrm{ml}$ DMEM/F12-Medium, gemischt im Verhältnis 1:1, überführt und in den Brutschrank gestellt. Während der Inkubationszeiten erfolgte die Vorbereitung der Schälchen bzw. der Objektträger mit einem gekammerten Aufsatz durch Beschichtung mit 2\%iger Gelatinelösung in 0,1 N HCl. Für die Objektträger wurde $1 \mathrm{ml}$ je Kammer und für die 3-cm-Schalen je $2 \mathrm{ml}$ verwendet. Die Objektträger und Schälchen wurden mit der Gelatinelösung für mindestens 30 Minuten im Brutschrank inkubiert.

Nach beendigtem Verdau wurden die Röhrchen geschwenkt und größere Gewebestücke abgesaugt. Dann wurden sie bei 1500 U/min für 10 Minuten zentrifugiert. Anschließend wurde der Überstand verworfen, die Pellets in einem Röhrchen in $20 \mathrm{ml}$ DMEM/F12Medium zusammengebracht und resuspendiert. Für das Präplattieren wurde jeweils die Hälfte der Zellsuspension auf eine $10 \mathrm{~cm}$ Schale gegeben und beide Schalen für 45 Minuten im Brutschrank inkubiert.

Die zum Ausplattieren vorbereiteten Objektträger und Schälchen wurden in dieser Zeit zweimal mit DMEM gespült und anschließend mit $2 \mathrm{ml}$ DMEM bis zum Ausplattieren gelagert.

Nach Ablauf der Inkubationszeit wurden die Zellen sorgfältig aus den Schalen abgesaugt und in ein Röhrchen überführt. Anschließend wurden $10 \mu \mathrm{l}$ der Zellsuspension mit $10 \mu \mathrm{l}$ Medium verdünnt und in einer Neubauer-

Zählkammer ausgezählt. Das Ausplattieren erfolgte nach folgendem Schema:

Tab.22 Angaben zur Zellkultur der neonatalen Kardiomyozyten

\begin{tabular}{|l|l|l|}
\hline Verwendung & Zellzahl/Volumen & Schälchen \\
\hline Planimetrie & $1 \times 10^{5} / 2 \mathrm{ml}$ & $30 \mathrm{~mm}$ \\
\hline Immunhistochemie & $20 \times 10^{3} / 5 \times 10^{-1} \mathrm{ml}$ & $4-$ Kammer-Objektträger \\
\hline$\beta$-Gal-Färbung & $15 \times 10^{4} / 3 \mathrm{ml}$ & $35 \mathrm{~mm}$ \\
\hline
\end{tabular}

\subsubsection{Kultur der neonatalen Kardiomyozyten}

Neonatale Kardiomyozyten wurden in 4:1(DMEM/M199)-Medium mit 2\% FCS ausplattiert und für 24 Stunden inkubiert. Dann erfolgte ein Mediumwechsel auf serumfreies 4:1(DMEM/M199)-Medium und in demselben Medium gegebenenfalls 
Virustransfektion, Apopotoseinhibitor- und AraC-Zusatz sowie Stimulation mit Phenylephrin. Die Zellen wurden anschließend weitere 48 Std. inkubiert. Nach mehrmaligem Waschen mit Medium wurden entweder die Schälchen an einem invertierten Mikroskop mit einer Videokamera und dem Programm Axiovision fotografiert oder die Zellen für die weiteren Analysen geerntet.

\subsubsection{Transfektion der Zellen mit Adenoviren}

Die Transfektion der adulten und neonatalen Rattenmyozyten erfolgte durch Adenovirusvermittelten Gentransfer.

Die adulten Myozyten wurden direkt beim Ausplattieren am Tag der Isolation transfiziert. Hierzu wurde die entsprechende Menge Virusstock mit Sucrosepuffer verdünnt und je nach Berechnung der MOI (Multiplicity of infection, Verhältnis der Viruspartikel zur Zellzahl) direkt zum Medium pipettiert. Nach drei Stunden wurde das Virus-haltige Medium abgesaugt und frisches M199-Medium auf die Schälchen gegeben. Die Zellen wurden weitere 24 Stunden kultiviert. Dann wurden die Schalen mit PBS gewaschen und die Zellen geerntet.

Die Transfektion der neonatalen Myozyten erfolgte am Tag nach Isolation ebenfalls gemäß MOI-Berechnung durch Zugabe des Virus zum Kulturmedium. Die Berechnung der MOI erfolgte mit Hilfe folgender Formel: MOI = (IE oder pfu $) /$ Zellzahl. Das benötigte Volumen wurde dementsprechend berechnet nach der Formel: Volumen (Virusstock) = MOI x Zellzahl / Viruskonzentration.

Am nächsten Morgen wurde ein Mediumwechsel durchgeführt. Die neonatalen Myozyten wurden für weitere 48 Stunden ohne Viruszugabe kultiviert. Anschließend folgte die mikroskopische Auswertung.

\subsection{Vorbereitung der Analyse}

\subsubsection{Lyse der Kardiomyozyten}

Nach der Entnahme der Myozytenpellets aus dem $-80^{\circ} \mathrm{C}-$ Gefrierschrank wurden alle Arbeitsschritte auf Eis durchgeführt. Der Lysepuffer wurde frisch angesetzt.

Zunächst wurden die Pellets in je $100 \mu$ Lysepuffer resuspendiert und gevortext. Anschließend wurden die Pellets für 30 Minuten auf Eis inkubiert und zwischendurch mehrmals gevortext. Mit Transferpipetten erfolgte die Überführung in Eppendorfgefäße 
und die mechanische Homogenisation durch mehrmaliges Aufziehen in Insulinspritzen. Abschließend wurden die Proben bei $10.000 \mathrm{U} / \mathrm{min}$ und $10^{\circ} \mathrm{C}$ für $10 \mathrm{~min}$. zentrifugiert, der Überstand in neue Eppendorfgefäße überführt und die Pellets verworfen. Die Myozytenlysate wurden bis zur Proteinbestimmung bei $-20^{\circ} \mathrm{C}$ gelagert.

\subsubsection{Herstellen von Lysaten aus Gewebeproben}

Die Proben wurden zwischen den Arbeitsschritten in flüssigem Stickstoff gelagert. Der Lysepuffer für Gewebeproben wurde frisch angesetzt.

Abhängig von der Probengröße wurden 300 bis $800 \mu$ l Lysepuffer zu den Proben gegeben. Jede Probe wurde mehrmals kurz mit dem Dispergierwerkzeug bei $35.000 \mathrm{U} / \mathrm{min}$ homogenisiert und danach zentrifugiert. Dieser Vorgang wurde so oft wiederholt bis keine festen Bestandteile mehr vorhanden waren. Das Werkzeug wurde zwischendurch immer wieder mit Wasser und Ethanol gereinigt. Die Gewebelysate wurden über Nacht bei $-20^{\circ} \mathrm{C}$ und für längere Zeit bei $-80^{\circ} \mathrm{C}$ gelagert.

\subsubsection{Photometrische Bestimmung der Lysate}

Die Bestimmung der Proteinkonzentration in den Lysaten erfolgte photometrisch (BCAProtein-Assay) nach dem 96-well-Mikroplate-Protokoll.

In eine 96-Kammern-Platte (96-well-Mikroplate) wurden $25 \mu 1$ pro Kammer der AlbuminStandardreihe pipettiert. Von den Lysaten wurden $3 \mu \mathrm{l}$ 1:20 mit $\mathrm{ddH}_{2} \mathrm{O}$ (doppelt destilliertem Wasser) verdünnt und in Doppelbestimmung $25 \mu 1$ je Kammer in die Platte pipettiert. Anschließend wurden $200 \mu \mathrm{l}$ Arbeitsreagenz (Working Reagent) je Kammer zugegeben und die Platte bei $37^{\circ} \mathrm{C}$ für $30 \mathrm{~min}$. inkubiert. Die Proteinbestimmung erfolgte im computergesteuerten Photometer bei einer Wellenlänge von $562 \mathrm{~nm}$. Mit dem Programm KC4 (BioTek) wurden die Ergebnisse ausgewertet. Aus der auf diese Weise bestimmten Proteinkonzentration wurde für jede Probe die notwendige Verdünnung errechnet, um alle Proben auf eine einheitliche Proteinkonzentration $\mathrm{zu}$ bringen. Die Proben wurden mit Lysepuffer und Blaupuffer entsprechend verdünnt und bei $-20^{\circ} \mathrm{C}$ gelagert.

\subsubsection{RNA-Isolation aus adulten Rattenmyozyten}

Für die Isolation der m-RNA wurde das RNeasy Mini Kit verwendet. Die Arbeitsschritte wurden nach dem beigefügten Protokoll durchgeführt. 
Ausplattierung und Ernten der Zellen, wie auch die Lagerung der Pellets erfolgte wie oben beschrieben.

Für die Homogenisation der Pellets wurden zunächst $350 \mu$ l RLT-Puffer und $1 \% \beta$ Mercaptoethanol auf die Pellets gegeben und anschließend gevortext. Der RLT-Puffer enthält Guanidinisothiocyanat, welches Proteine und somit auch die RNAsen denaturiert. Um unlösliche Zellreste zu entfernen, wurden die Proben auf eine QIAshredder-Säule überführt, welche sich in einem $2 \mathrm{ml}$ Auffanggefäß befand, und für $2 \mathrm{~min}$. bei maximaler Geschwindigkeit zentrifugiert. Im Anschluss wurden die Lysate in dem Auffanggefäß 1:1 mit $70 \%$-igem Ethanol gemischt und jeweils $700 \mu$ dieser Mischung in eine RNeasy Mini-Säule überführt. Die Säule wurde nun in einem 2-ml-Eppendorfgefäß für $15 \mathrm{~s}$ bei $10.000 \mathrm{U} / \mathrm{min}$ zentrifugiert. Die Membran in der RNeasy Mini-Säule bindet RNA ab einer Größe von etwa 200 Basenpaaren (vorwiegend m-RNA), was durch Ethanol gefördert wird.

Es folgten im Anschluss drei Waschschritte mit Puffern aus dem RNeasy Mini Kit, um letzte Verunreinigungen wie beispielsweise DNA-Reste zu beseitigen. Zunächst wurde hierfür $700 \mu 1$ RW1-Puffer auf die RNeasy-Säule gegeben und für $15 \mathrm{~s}$ zentrifugiert. Die Zentrifugation erfolgte bei $10.000 \mathrm{U} / \mathrm{min}$, wie auch im darauffolgenden Schritt. Das $2 \mathrm{ml}-$ Gefäß und die Flüssigkeit wurden verworfen. Die RNeasy Säule wurde in ein neues 2 mlEppendorfgefäß überführt und $500 \mu 1$ RPE-Puffer auf die Säule gegeben. Erneut wurde für 15 s zentrifugiert und die Flüssigkeit verworfen. Ein weiteres Mal wurde $500 \mu \mathrm{l}$ RPEPuffer auf die Säule gegeben und für 2 Minuten nun bei maximaler Geschwindigkeit zentrifugiert, um auch die Ethanolreste zu beseitigen. Zuletzt konnte die gereinigte m-RNA von der Membran gelöst werden. Hierzu wurde die Säule in ein neues 1,5-ml-Gefäß überführt und $50 \mu \mathrm{l}$ RNase-freies Wasser direkt auf die Membran gegeben. Das Gefäß wurde für 1 Minute bei $10.000 \mathrm{U} / \mathrm{min}$ zentrifugiert. Die gereinigte m-RNA wurde in dem Elutionsgefäß bei $-80^{\circ} \mathrm{C}$ gelagert.

\subsubsection{Herstellung der cDNA}

Für die Herstellung der cDNA aus der extrahierten mRNA wurde das iScript cDNA Synthese Kit verwendet und alle Schritte nach Protokoll durchgeführt.

$200 \mathrm{ng}$ der gewonnenen mRNA der einzelnen Proben wurden in ein Eppendorfgefäß pipettiert. Das unterschiedliche Volumen der einzelnen Proben wurde ausgeglichen durch Zugabe von Nuclease-freiem Wasser, bis das Endvolumen $15 \mu \mathrm{l}$ betrug. Dann wurden zu 
jeder Probe $4 \mu 15 \mathrm{x}$ iSkript Reaktionsmix, der Oligonukleotide und Oligo-dT-Primer enthält, und $1 \mu 1$ iSkript Reverse Transkriptase hinzugefügt, alles gut gemischt und kurz zentrifugiert. Zum Ausschluss einer DNA-Kontamination diente eine Kontrolle mit RNA und Wasser. Durch Hinzufügen der Reversen Transkriptase wurde die Reaktion gestartet. Hierbei lagern sich die Primer an den mRNA-Strängen an und die Reverse Transkriptase synthetisiert aus den Oligonukleotiden einen $\mathrm{zu}$ dem jeweiligen mRNA-Strang komplementären DNA-Strang, die cDNA. Die gewonnene cDNA liegt somit in quantitativ gleichem Verhältnis zu der in den Proben befindlichen mRNA vor. Zunächst wurden die Reaktions-Ansätze für 5 min. bei Raumtemperatur $\left(\right.$ ca. $22^{\circ} \mathrm{C}$ ) belassen. Dann folgte die eigentliche Synthese-Phase in einem Thermomixer bei $42^{\circ} \mathrm{C}$. Nach $30 \mathrm{~min}$. wurde die Synthese durch eine kurze Denaturierungsphase von $5 \mathrm{~min}$. bei $85{ }^{\circ} \mathrm{C}$ gestoppt. Die Lagerung der Proben mit der auf diese Weise hergestellten cDNA erfolgte bei $-20^{\circ} \mathrm{C}$.

\subsection{Analyse}

\subsubsection{Durchführung der RealTime-Polymerase-Kettenreaktion (RT-PCR)}

Es wurde eine semiquantitative Echtzeit-Polymerase-Kettenreaktion (RT-PCR) mittels des iQ 5 Multicolor Cyclers von BioRad nach Herstellerangaben durchgeführt. Zur Normalisierung wurde GAPDH als internes Kontroll-Gen verwendet.

Zunächst wurden die cDNA-Proben auf Eis aufgetaut. Dann wurden $2 \mu \mathrm{l}$ der cDNALösung wurden in eine 96-Kammern-Platte pipettiert. Ebenso wurde $1 \mu 1$ cDNA-Standard aus Rattenkardiomyozyten in absteigender Konzentration von 1024 fg bis 3,9 ag und eine Kontrolle nur mit dem verwendeten RNAse-freien Wasser nebeneinander in die Kammern pipettiert. Die Proben und der Standard wurden jeweils in Doppelbestimmung auf die Platte aufgetragen. Danach erfolgte die Zugabe von $6 \mu$ l autoklaviertem Wasser, je $1 \mu 1$ der vorwärts- und rückwärts-gerichteten Primer und $10 \mu \mathrm{l}$ iQ Sybr Green Supermix in jede Kammer. Der Mix beinhaltete die i Taq ${ }^{\mathrm{TM}}$ DNA-Polymerase, Magnesium-Ionen zur Aktivierung des Enzyms, Nukleosidtriphosphate und den Farbstoff SYBR ${ }^{\circledR}$ Green I. Es wurden Primer für ANF, BNP, $\beta$ MHC und GAPDH verwendet, deren Sequenzen bei den Materialien angegeben sind.

Die Platte wurde nun in den Cycler eingesetzt und die PCR gestartet. Nach längerer anfänglicher Denaturierung der DNA für $3 \mathrm{~min}$. bei $95^{\circ} \mathrm{C}$ wurde der sich wiederholende Zyklus aus Anlagerung der Primer (Annealing), Elongation und erneuter Denaturierung 
gestartet. Die DNA-Polymerase synthetisiert hierbei nach der Anlage der Primer (Annealing) aus den Nukleosidtriphosphaten einen zweiten DNA-Strang (Elongation), sodass doppelsträngige DNA (dsDNA) entsteht. Mit der Denaturierung werden die Doppelstränge wieder getrennt und an den Einzelsträngen kann die Synthese nach Anlagerung der Primer erneut beginnen.

Zeiten und Temperaturen wurden für die Zyklen wie folgt gewählt:

Tab.23 Temperaturangaben für die Durchführung der RT-PCR

\begin{tabular}{|l|l|l|}
\hline Phase & Temperatur & Zeit \\
\hline Denaturierung & $95^{\circ} \mathrm{C}$ & $15 \mathrm{~s}$ \\
\hline Annealing & $60^{\circ} \mathrm{C}$ & $10 \mathrm{~s}$ \\
\hline Elongation & $72^{\circ} \mathrm{C}$ & $15 \mathrm{~s}$ \\
\hline
\end{tabular}

Bei der RT-PCR wird nach jeder Elongations-Phase die Fluoreszenz des Farbstoffes SYBR $\AA$ Green I in Echtzeit gemessen. Dieser Farbstoff bindet an Nukleinsäuren doppelsträngiger DNA und ändert hierbei seine Lichtabsorption, welche durch den Cycler gemessen wird, sodass die Fluoreszenz-Intensität direkt proportional zu der Menge der synthetisierten dsDNA ist.

Zum Abschluss der RT-PCR wurde durch das sog. „Melting“ eine Schmelzkurve erstellt. Dabei wurde beginnend bei $51^{\circ} \mathrm{C}$ in $0,5^{\circ} \mathrm{C}$-Schritten die Temperatur erhöht. Bei einer bestimmten Temperatur denaturiert das spezifische DNA-Fragment und setzt den Farbstoff frei, wodurch es zu einem „Peak“ (Ausschlag) in der Schmelzkurve kommt. Unspezifische Fragmente denaturieren meist schneller, weswegen dieser Schritt eine Überprüfung der Spezifität darstellt.

\subsubsection{SDS-Polyacrylamid-Gelelektrophorese (SDS-PAGE)}

Vor dem Western Blot wurden die in den Proben enthaltenen Proteine in einem SDS (Sodiumdodecylsulfat)-Polyacryalamid-Gel nach der Methode von Laemmli (Laemmli 1970) elektrophoretisch aufgetrennt. Es wurden hierzu 12,5 \%-ige Gele analog den Herstellerangaben mit einem BioRad mini Protean II -System gegossen. Die Gele bestanden aus Trenngel und Sammelgel. Nach der Polymerisation der Gele wurden die Taschen des Sammelgels je nach Konzentration der ready-to-use Proben mit 10-40 $\mu 1$ der Proben sowie mit einem Protein-Standard beladen. Der Gellauf erfolgte in Laufpuffer für 
30 min bei 0,05 A. für die Durchwanderung des Sammelgels und anschließend bei 0,08 A für etwa 1 Stunde für die Wanderung der Proteine im Trenngel.

\subsubsection{Western Blot und Immunfärbung}

Nach beendigtem Gellauf erfolgte der Transfer der Proteine auf eine NitrocelluloseMembran (Blotting). Hierbei waren die einzelnen Bestandteile in folgender Weise senkrecht in der Transferkammer in ein horizontales elektrisches Feld eingespannt: von der Anode ausgehend 2 Schwämme, 2 Filterpapiere, Nitrocellulosemembran, Gel, 2 Filterpapiere und 2 Schwämme. Der Transfer erfolgte für 2 Std. bei $0,5 \mathrm{~A}$ in Transferpuffer. Der Eisakku zur Kühlung des Systems wurde nach 1 Std. gewechselt. Nach erfolgtem Blot wurde die Membran entnommen, mit Ponceau-Rot gefärbt und anhand der Banden zwischen nachzuweisendem Protein und Standardprotein geschnitten. Die Membranteile wurden über Nacht bei $4{ }^{\circ} \mathrm{C}$ oder für $1 \mathrm{Std}$. bei Raumtemperatur in $5 \%$ Milchpuffer geblockt, um bei der Immunfärbung unspezifische Bindungen der Antikörper zu vermeiden.

Nach dreimaligem Waschen mit TBS-tween erfolgte die Inkubation für eine halbe bis 2 Std. mit dem ersten Antikörper. Anschließend wurden die Membranteile 3 Mal für jeweils 5 min. mit TBS-tween (TRIS-gepufferte Kochsalzlösung mit Tween20) gewaschen und dann mit dem zweiten Antikörper für 1 Std. inkubiert. Die Antikörper waren in 0,5 \%-igem oder 5\%-igem Milchpuffer oder einer 5\%-igen BSA-Lösung gelöst, je nach Angaben des Herstellers. Die Membranteile wurden wieder gewaschen wie beschrieben. Zur Detektion der Banden wurde die Membran mit dem Chemilumineszenz-Substrat nach Herstellerangaben inkubiert. Anschließend wurden die Membranteile vorsichtig getrocknet und in Folie in eine Fotokassette gelegt. In der Dunkelkammer wurde das Signal der Antikörper mit Röntgenfilmen sichtbar gemacht.

\subsubsection{B-Galaktosidase-Gene-Reporter-Assay (B-Gal-Färbung)}

Zur Ermittlung der Transfektioneffizienz bei verschiedenen MOI wurde bei mit nls-LacZViren transfizierten Kardiomyozyten ein Aktivitätsnachweis der $\beta$-Galaktosidase durchgeführt. Nach Ende der Kultur wurden die Zellen mit PBS gewaschen und dann fixiert. Hierfür wurde $1 \mathrm{ml}$ einer 0,2 \%igen Glutaraldehyd-Lösung in PBS in die Schalen gegeben und für $15 \mathrm{~min}$. bei $37^{\circ} \mathrm{C}$ belassen. Die Schalen wurden anschließend einmal mit PBS gewaschen. Die Färbelösung wurde frisch angesetzt und davon $1 \mathrm{ml}$ in jede Schale 
gegeben. Die Zellen wurden für eine halbe bis $3 \mathrm{Std}$. bei $37^{\circ} \mathrm{C}$ inkubiert. Bei im Mikroskop sichtbarer Blaufärbung wurde die Lösung abgesaugt und die Zellen mit PBS gewaschen. Die Auszählung der Zellen erfolgte am Lichtmikroskop.

\subsubsection{Immunfluoreszenzmikroskopie}

Die Kultur der Zellen für Immunfluoreszenz erfolgte in Objektträgern mit aufgesetzten Kammern. Nach mehrtägiger Kultur wurden die Zellen zweimal mit PBS gewaschen. Zur Fixierung wurden die Zellen mit einer Lösung aus Aceton und Methanol im Verhältnis 3:7 für 20 min. bei $-20^{\circ} \mathrm{C}$ inkubiert. Die Lösung wurde abgesaugt und die Zellen für dreimal für je 5 min. erneut mit PBS gewaschen. Anschließend wurden die Zellen über Nacht bei $4^{\circ} \mathrm{C}$ mit $1 \%$ iger BSA-Lösung in PBS inkubiert.

Zur Permeabilisierung wurde danach eine Lösung, die 0,1 \% Triton-X-100 (Octoxinol-9) und $1 \% \mathrm{BSA}$ in PBS enthielt, auf die Zellen gegeben und für 20 min. bei Raumtemperatur belassen. Anschließend wurden die Zellen für weitere 40 min. in $1 \%$-igem BSA in PBS bei Raumtemperatur inkubiert. In dieser Zeit wurden die Antikörper-Verdünnungen in $1 \%$ igem BSA in PBS angesetzt. Nun wurden die Kammern von den Objektträgern entfernt und diese auf ein feuchtes Tuch in 10-cm-Schälchen gelegt. So wurden die Schälchen für 1 Std. bei $37^{\circ} \mathrm{C}$ mit dem ersten Antikörper inkubiert. In Objektträgerständern wurden die Objektträger anschließend dreimal mit PBS gewaschen. Danach erfolgte die Inkubation mit dem Zweitantikörper wiederum für $1 \mathrm{Std}$. bei $37^{\circ} \mathrm{C}$. Die Objektträger wurden dann erneut dreimal mit PBS gewaschen und ein weiteres Mal mit $\mathrm{ddH}_{2} \mathrm{O}$. Pro Feld wurde nun 1 Tropfen Festigungsmedium (Vecta Shield Mounting Medium und der DNA-markierende Fluoreszenzfarbstoff DAPI (4',6-Diamidino-2-phenylindol)) auf die Objektträger gegeben, mit einem Deckgläschen abgedeckt und beides an den Seiten mit Nagellack abgedichtet. Die Auswertung wurde am Fluoreszenz-Mikroskop durchgeführt.

\subsubsection{Immunhistochemie}

Die Versuchstiere wurden $\mathrm{zu}$ verschiedenen Zeitpunkten nach Infarkt- oder ShamOperation durch Genickbruch in Isoflurannarkose getötet. Die Herzen wurden entnommen, nach Langendorff retrograd mit physiologischer Kochsalzlösung perfundiert, um das Blut aus den Gefäßen zu entfernen, und anschließend in 4 \%iger Formalinlösung fixiert. Danach erfolgte die Einbettung in Paraffin. Die Präparate konnten dann geschnitten werden. 
Zur Färbung wurden die Schnitte zweimal für jeweils 10 min. mit Xylol inkubiert. Dies diente der Entparaffinierung. Anschließend erfolgte die Inkubation in einer absteigenden Alkohol-Reihe und schließlich in destilliertem Wasser, wodurch die Schnitte in ein wässriges Medium überführt wurden. Die Schnitte wurden zum besseren Antigennachweis mit Zitratpuffer für $15 \mathrm{~min}$. in der Mikrowelle vorbehandelt. Dann wurden sie in destilliertem Wasser und später in PBS gewaschen. Zur Blockade der endogenen Peroxidase wurden die Schnitte nun für 10 min. in einer Lösung aus 3 \%igem Wasserstoffperoxid und PBS inkubiert und anschließend mit PBS gespült. Dies diente der Blockade der endogenen Peroxidase. Nun wurden die unspezifischen Proteinbindungsstellen auf den Gewebeschnitten durch kurze Inkubation in 4 \%igem BSA in einem Gemisch aus 0,1 \%igem Triton X-100 in PBS und anschließend einer einstündigen Inkubation bei $37^{\circ} \mathrm{C}$ in $0,4 \%$-igem BSA in PBS geblockt. Dann erfolgte die eineinhalb-stündige Inkubation mit dem spezifischen, gegen MLP gerichteten PrimärAntikörper. Der Antikörper wurde hierfür in verschiedenen Konzentrationen in $1 \%$ BSA in PBS verdünnt. Für die sich anschließende Detektion des Primär-Antikörpers wurde ein Detektions-Satz (Zymed) verwendet. Zunächst erfolgte die Inkubation mit dem HRP(horseradish-peroxidase)-Konjugat, dann ein Waschschritt mit PBS und zuletzt die Inkubation mit DAB(diaminobenzidine)-Chromogen nach Herstellerangaben. Nun wurde eine Hämalaun-Färbung nach Mayer zur Färbung der Zellkerne durchgeführt. Nach der Färbung wurden die Schnitte in aufsteigend konzentrierten Alkohol-Lösungen und mit Xylol inkubiert. Das Eindecken erfolgte mit Entellan.

\subsubsection{Planimetrie}

Die neonatalen Kardiomyozyten wurden am Tag nach der Isolation in serumfreies 4:1DMEM/M199-Medium überführt und in diesem Medium transfiziert. Sofort im Anschluss wurden $20 \mu 1$ Phenylephrin auf $2 \mathrm{ml}$ Medium (1:100) hinzugegeben. Ebenso wurden der Fibroblasteninhibitor Cytosin- $\beta$-D-Arabinofuranosid (AraC) und der Apoptoseinhibitor ZVAD-FMK (Z-Val-Ala-Asp(OMe)- $\left.\mathrm{CH}_{2} \mathrm{~F}\right)$ für ein deutlicheres Stimulationsergebnis in das Medium gegeben. Dies sollte eine Vermehrung der Fibroblasten und die Apoptose der Myozyten verhindern. Es wurden jeweils. $10 \mu 1$ der Substanzen auf $2 \mathrm{ml}$ Medium gegeben (Konzentration 10mM). 
Nach 48-stündiger Inkubation wurde das Medium abgesaugt und durch frisches 4:1Medium ersetzt. Die Zellen wurden am computergesteuerten Mikroskop ausgemessen und die Auswertung erfolgte mit dem Computerprogramm AxioVision (Zeiss).

\subsection{8 [ $\left.{ }^{3} \mathrm{H}\right]$-Leucin-Aufnahme $\left(\left[{ }^{3} \mathrm{H}\right]\right.$-Leucin-uptake $)$}

Die Versuche wurden analog den Angaben von Jacobshagen et al. (2007) durchgeführt. Nach den erfolgten Isolationen wurden die adulten Kardiomyozyten transfiziert und für 3 Std. bei $37^{\circ} \mathrm{C}$ inkubiert. Dann wurde das Medium abgesaugt und $5 \mathrm{ml}$ frisches M199Medium zugegeben. Die Zellen wurden so über Nacht inkubiert. Am nächsten Morgen wurden $3 \mathrm{ml}$ Medium abgesaugt. Etwa 24 Std. nach Isolation wurde in die restlichen $2 \mathrm{ml}$ Medium $10 \mu \mathrm{l}$ der mit Tritium radioaktiv markierten Aminosäure Leucin in einer Aktivität von $1 \mu \mathrm{Ci} / \mu \mathrm{l}$ zugegeben. Die Zellen wurden nun für $4 \mathrm{Std}$. bei $37^{\circ} \mathrm{C}$ inkubiert.

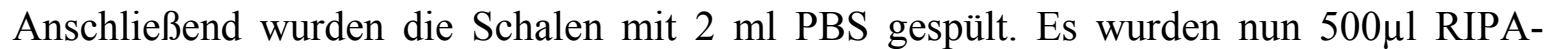
Puffer zur Lyse auf die Zellen gegeben und die Schalen für 15 min. auf Eis inkubiert. Die Zellen wurden abgeschabt und das Lysat wurde in 2-ml-Zentrifugenröhrchen überführt. $250 \mu \mathrm{l}$ kalte $20 \%$ ige Trichloressigsäure (TCA) in $\mathrm{ddH}_{2} \mathrm{O}$ wurden in jedes Röhrchen gegeben und für weitere 15 min. auf Eis inkubiert. Die Röhrchen wurden dann bei 14.000 U/min für 20 min. zentrifugiert. Der Überstand wurde abgenommen und verworfen. Die Pellets wurden in $250 \mu 15 \%$ iger TCA resuspendiert und wiederum bei $14.000 \mathrm{U} / \mathrm{min}$. für 20 min. zentrifugiert. Der Überstand wurde erneut verworfen und die Pellets in $300 \mu 10,2$ $\mathrm{N} \mathrm{NaOH}$ resuspendiert. Anschließend wurden die Röhrchen für $2 \mathrm{~min}$. im Thermocycler bei $50{ }^{\circ} \mathrm{C}$ geschüttelt. Nun wurden $1,5 \mathrm{ml}$ eines Szintillationsuniversalcocktails je Röhrchen hinzugegeben und die Lichtemission im Szintillationscounter gemessen.

\subsection{Statistische Auswertung}

Die Versuchsergebnisse sind als Mittelwerte \pm Standardfehler des Mittelwertes angegeben. Die untersuchten Gruppen wurden mit Hilfe eines zweiseitigen ungepaarten Student's tTest auf Unterschiede untersucht. Bei Experimenten mit mehr als 2 untersuchten Gruppen wurde eine ANOVA mit einem Bonferroni Post-Test durchgeführt. Ein Unterschied mit einer Irrtumswahrscheinlichkeit von $\mathrm{p}<0,05$ wurde als statistisch signifikant akzeptiert. 


\section{Ergebnisse}

\subsection{Nukleäre Relokalisation von MLP in Infarktherzen}

Um die Lokalisation von MLP in Herzmuskelgewebe nach Infarkt zu untersuchen und somit einen Hinweis auf eine mögliche nukleäre Lokalisation von MLP zu erhalten, wurden Mäuse zwei Stunden, zwei Tage sowie zwei, vier und acht Wochen nach Koronarligatur getötet und Paraffinschnitte der Herzen hergestellt. Als Vergleich dienten jeweils Paraffinschnitte sogenannter Sham-Mäuse, die einer Scheinoperation mit Thoraxeröffnung unterzogen worden waren. Es zeigte sich eine deutliche nukleäre MLPFärbung nach einem Zeitraum von zwei Tagen nach Infarkt. Diese Färbung konnte ebenfalls nach zwei Wochen noch nachgewiesen werden, wurde jedoch in den späteren Präparaten immer schwächer. Nach acht Wochen zeigte sich eine vorwiegend zytoplasmatische MLP-Färbung, während die nukleäre Färbung weitgehend verschwunden war. Die Zellen mit der nukleären sowie der zytoplasmatischen MLP-Färbung fanden sich vornehmlich im Infarkt-Randbereich. Dargestellt sind exemplarisch die Färbungen nach zwei Tagen.

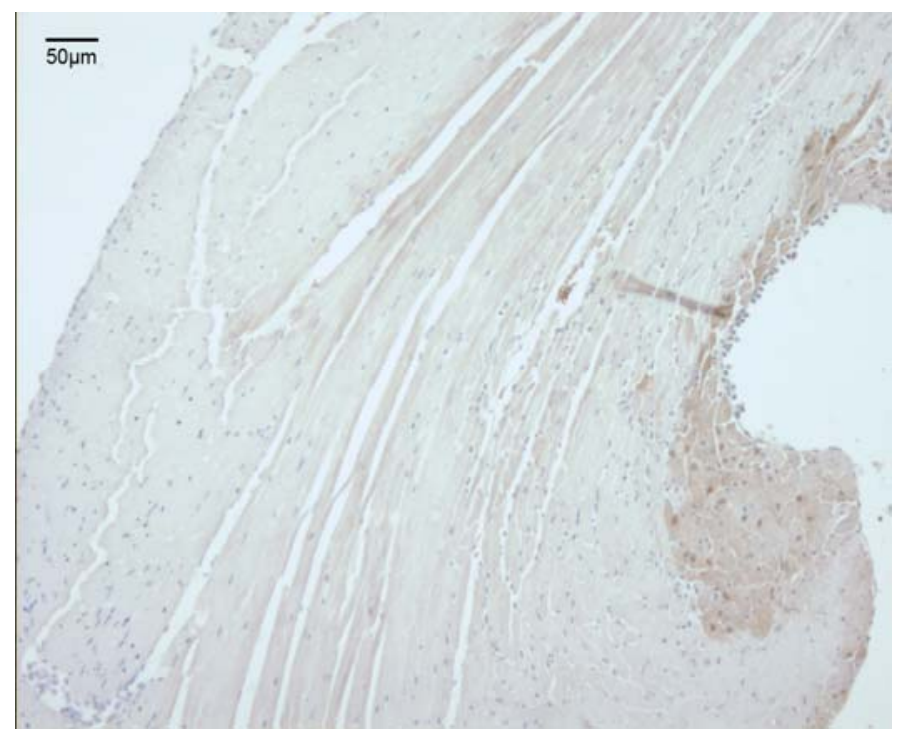
Abb. 1
Infarkt-operierte Mäuse nach zwei Tagen. Der Ausschnitt zeigt einen Teil der linken Herzwand und umfasst den Infarktbereich.
a) 10 fache Vergrößerung: Die braun gefärbten Areale liegen im Infarktrandgebiet und zeigen eine deutliche zytoplasmatische Braunfärbung als Zeichen der MLP-Detektion. 


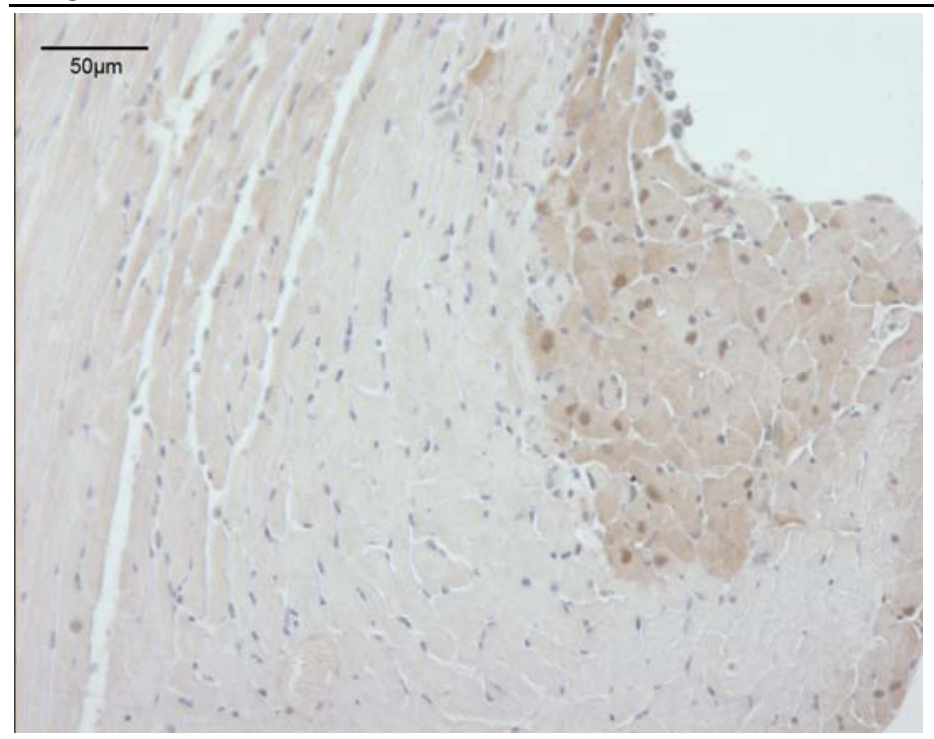

b) 20 fache Vergrößerung: In dieser Vergrößerung ist die nukleäre Färbung der Zellen und damit die verstärkt nukleäre Lokalisation von MLP zu erkennen.

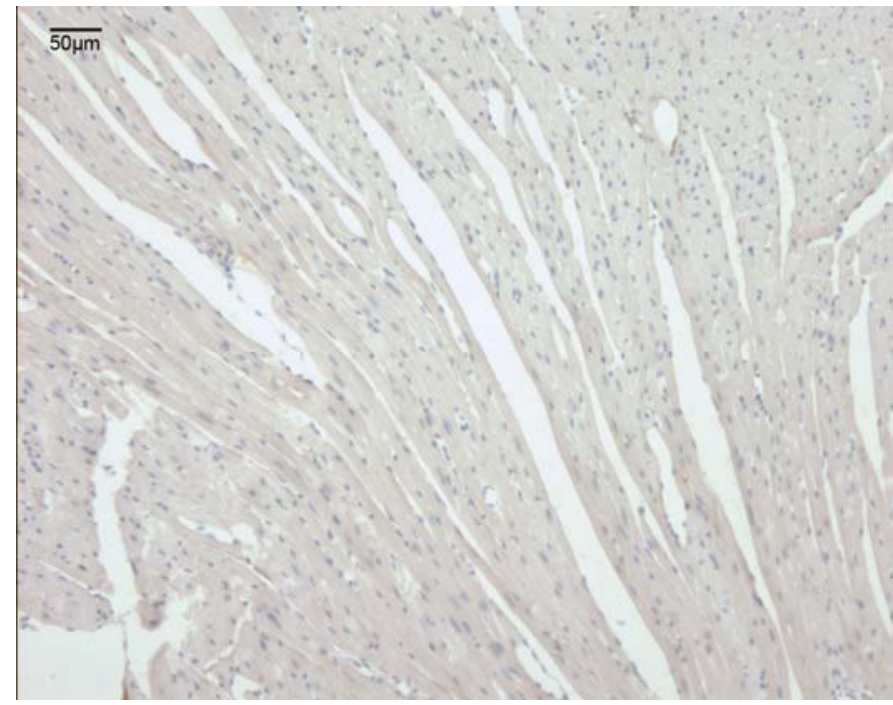

Abb. 2

Kontrollmäuse. Der Ausschnitt zeigt einen Teil des linken Ventrikels. In beiden Vergrößerungen ist keine hervortretende nukleäre oder zytoplasmatische MLPDetektion zu erkennen.

a) 10fache Vergrößerung

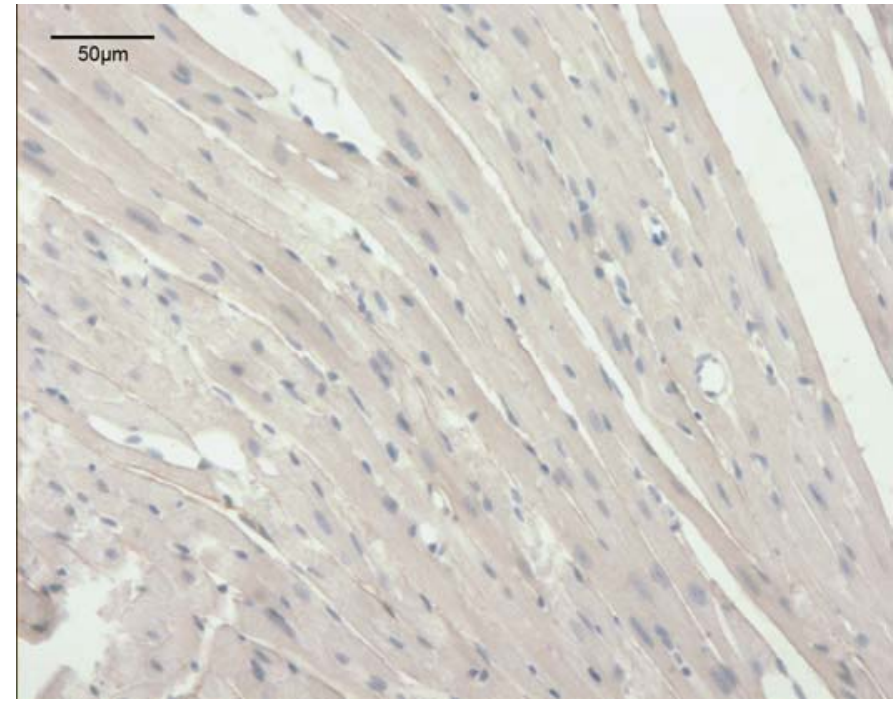

b) 20fache Vergrößerung 


\subsection{Expression von MLP in der Herzmuskelhypertrophie}

Die MLP-Expression wurde zu zwei verschiedenen Zeitpunkten nach Myokardinfarkt in Mäuseherzen durch RT-PCR und Western-Blot-Analysen aus den Ventrikellysaten bestimmt. Zusätzlich wurden die Herzen auf Hypertrophie-Merkmale untersucht.

\subsubsection{Ausbildung von Hypertrophie-Merkmalen in den Infarktherzen}

$\mathrm{Zu}$ verschiedenen Zeitpunkten nach Infarkt wurden die Mäuse getötet und die Herzen entnommen. Bereits nach drei Tagen sowie auch noch nach zwei Wochen wiesen die Herzen ein deutlich erhöhtes Gewicht auf als Zeichen einer signifikanten Hypertrophie (Daten nicht gezeigt). Ebenfalls wurden die Herzen mittels RT-PCR und Western Blot zu verschiedenen Zeitpunkten auf veränderte Expression der Hypertrophie-Marker untersucht. Exemplarisch sind die Ergebnisse der Analyse der BNP-Expression in der RT-PCR nach zwei Wochen dargestellt. Die Infarktherzen zeigten eine signifikant erhöhte BNPExpression (Mittelwert 0,64 $\pm 0,104, n=9)$ im Vergleich zu den Shamherzen $(0,32 \pm 0,054$, $\mathrm{n}=9, \mathrm{p}=0,014)$ auf.

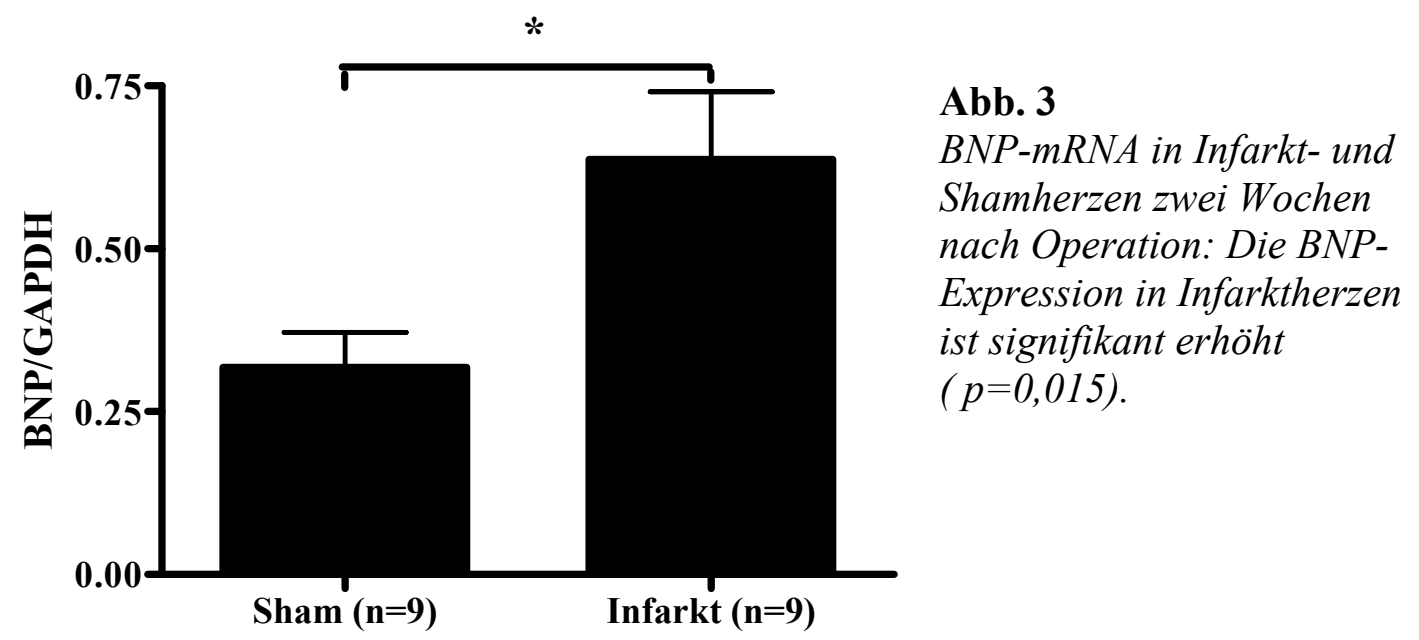

\subsubsection{Expression von MLP zwei Wochen nach Myokardinfarkt}

Zwei Wochen nach Koronarligatur oder Sham-Operation wurden die Versuchstiere getötet, die Herzen entnommen und Ventrikellysate für die RT-PCR und den Western Blot hergestellt. Die Expression von MLP war in der RT-PCR der Infarktherzlysate um 46\% 
höher (Mittelwert 2,27 $\pm 0,78, n=9$ ) als in den Lysaten der Shamherzen $(1,23 \pm 0,11, n=9$ ).

Der Unterschied war jedoch nicht signifikant aufgrund der starken Schwankungen in den einzelnen Präparaten $(p=0,201)$. Für die MLP-Expression auf Proteinebene ergab der Western Blot keinen Unterschied in den beiden Vergleichsgruppen (Mittelwerte 1,06 $\pm 0,15$, und $1,07 \pm 0,17$, jeweils $n=9, p=0,98)$.
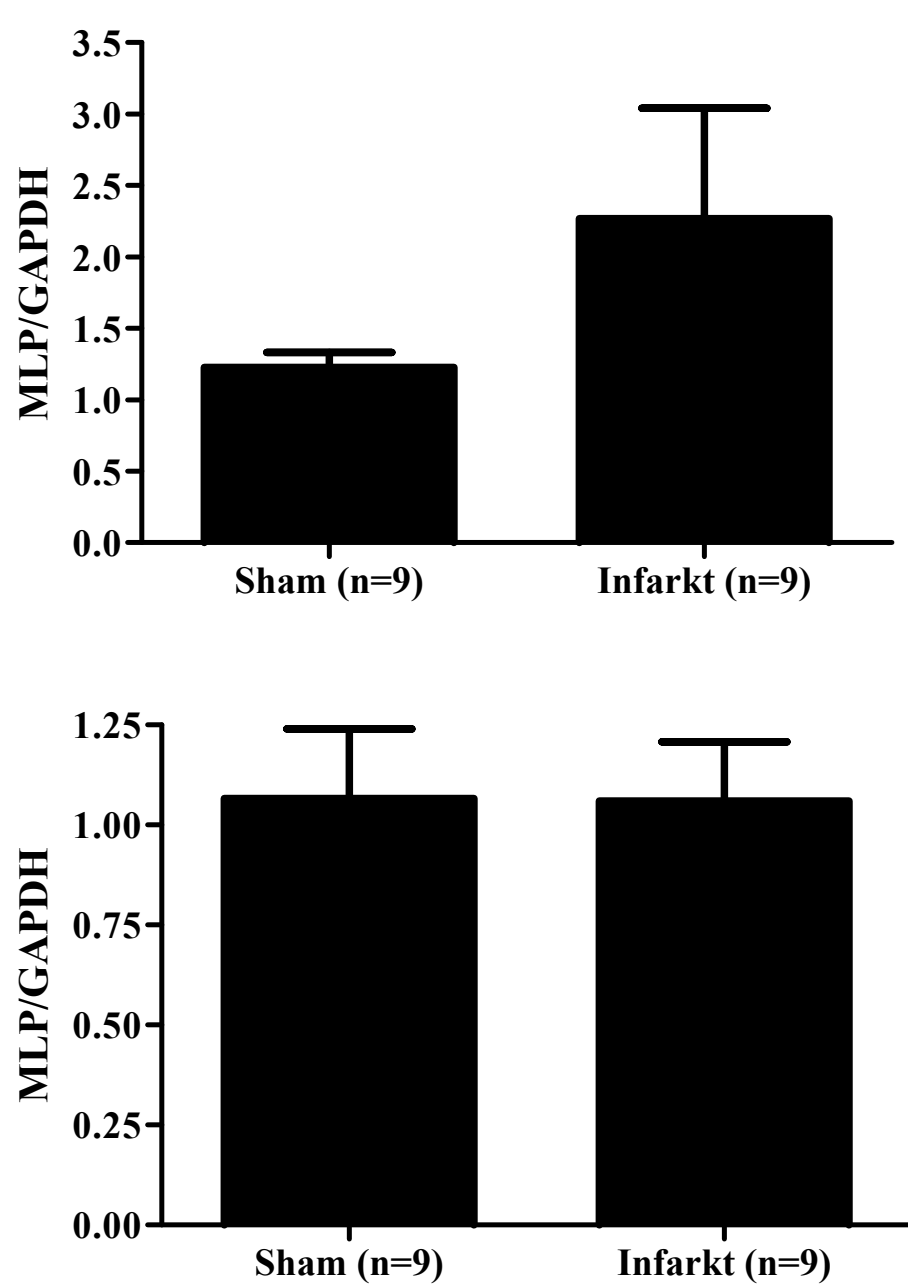

Abb. 4

$M L P-m R N A$ in Infarktund Shamherzen zwei Wochen nach Operation: Die MLP-Expression ist um $46 \%$ höher in den Infarktherzen, jedoch nicht signifikant erhöht $(p=0,201)$.

Abb. 5

MLP-Expression im Western Blot in Infarkt- und Shamherzen nach zwei Wochen: Es zeigt sich kein Unterschied in den beiden Gruppen $(p=0,98)$.

\subsubsection{Expression von MLP drei Monate nach Infarkt}

Drei Monate nach Koronarligatur wurde ebenfalls die MLP-Expression auf mRNA-Ebene in den Ventrikellysaten untersucht. Es zeigte sich auch hier kein Unterschied der Expression von MLP in Infarktherzen $(0,37 \pm 0,05, \mathrm{n}=7) \mathrm{im}$ Vergleich zu der Expression in den Shamherzen $(0,37 \pm 0,03, n=3, p=0,077)$. 


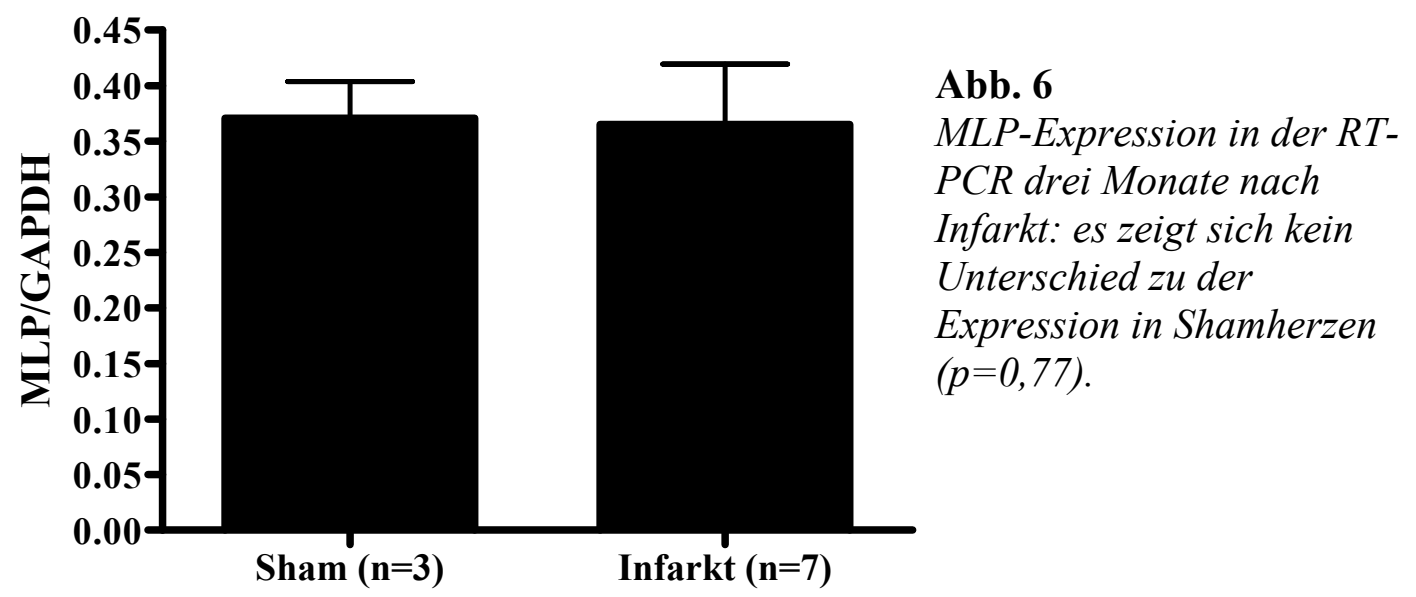

\subsection{Funktionsfähigkeit des nls-MLP-Virus}

Um den Einfluss eines nukleären MLP auf die Herzmuskelhypertrophie zu überprüfen, wurde analog den Versuchen von Kong et al. in Skelettmuskelzellen ein um das nukleäre Lokalisationssignal SV40 ergänztes MLP, das nls-MLP, durch Gentransfer über ein Replikations-defizientes Adenovirus in neonatalen und adulten Rattenkardiomyozyten exprimiert (Kong et al. 1997).

\subsubsection{Bestimmung der Transfektionseffizienz}

Die Effizienz der adenoviralen Transfektion von adulten und neonatalen Rattenkardiomyozyten abhängig von der Anzahl der Viren pro Zelle (MOI) wurde abgeschätzt anhand der Transfektion mit einem Virus, das eine nukleär lokalisierte $\beta$ Galaktosidase exprimiert (nls-LacZ). Diese lässt sich durch die Reaktion mit dem Farbstoff $\mathrm{X}-\mathrm{Gal}$ nachweisen. Es wurden adulte und neonatale Rattenkardiomyozyten aus jeweils drei verschiedenen Isolationen transfiziert, für 48 Stunden kultiviert und anschließend die gefärbten und ungefärbten Zellen ausgezählt. Der Anteil der gefärbten Zellen zeigte die Effizienz der Transfektion mit dem nls-LacZ-Virus bei der jeweils eingesetzten Virusmenge (MOI). Die Transfektionseffizienz nahm mit steigender MOI zu und erreichte bei einer MOI von 50 in neonatalen Kardiomyozyten ihr Maximum mit $71 \pm 1,53 \%$. Für adulte Kardiomyozyten lag die Anzahl der transfizierten Zellen hier bei $70 \pm 4,36 \%$. Ab eingesetzten Virusmengen von MOI > 50 zeigte sich eine starke Zunahme der toten Zellen sowohl bei den neonatalen als bei den adulten Kardiomyozyten, ohne dass ein weiterer 
wesentlicher Anstieg der Transfektionseffizienz gegenüber der MOI von 50 erzielt werden konnte.

a)

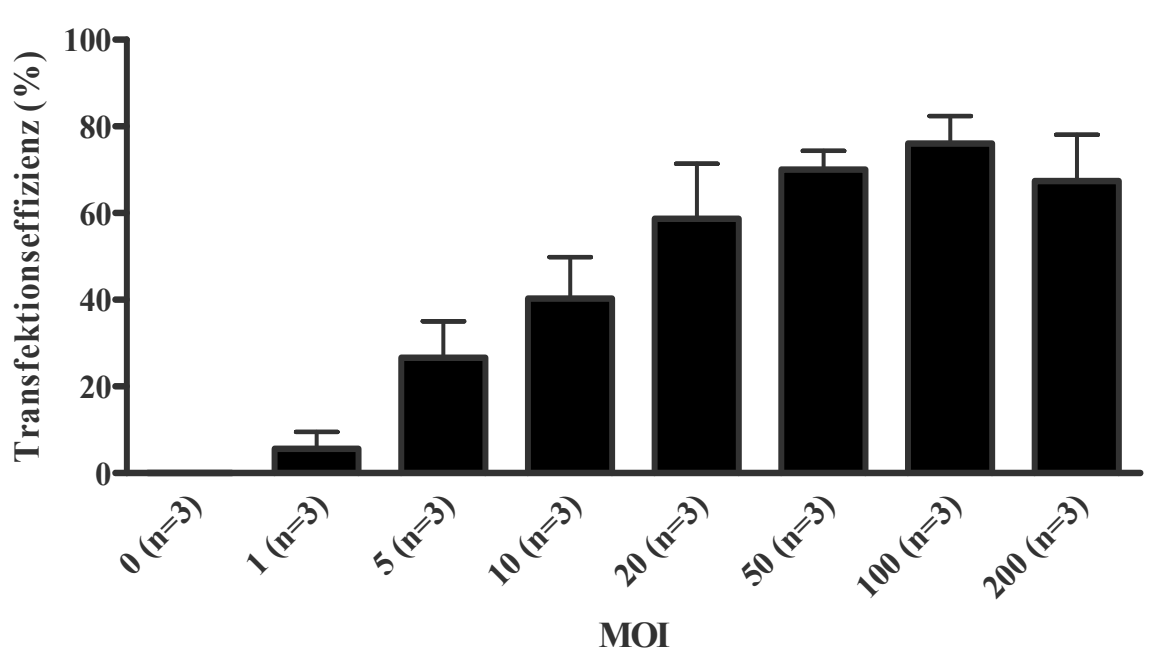

b)

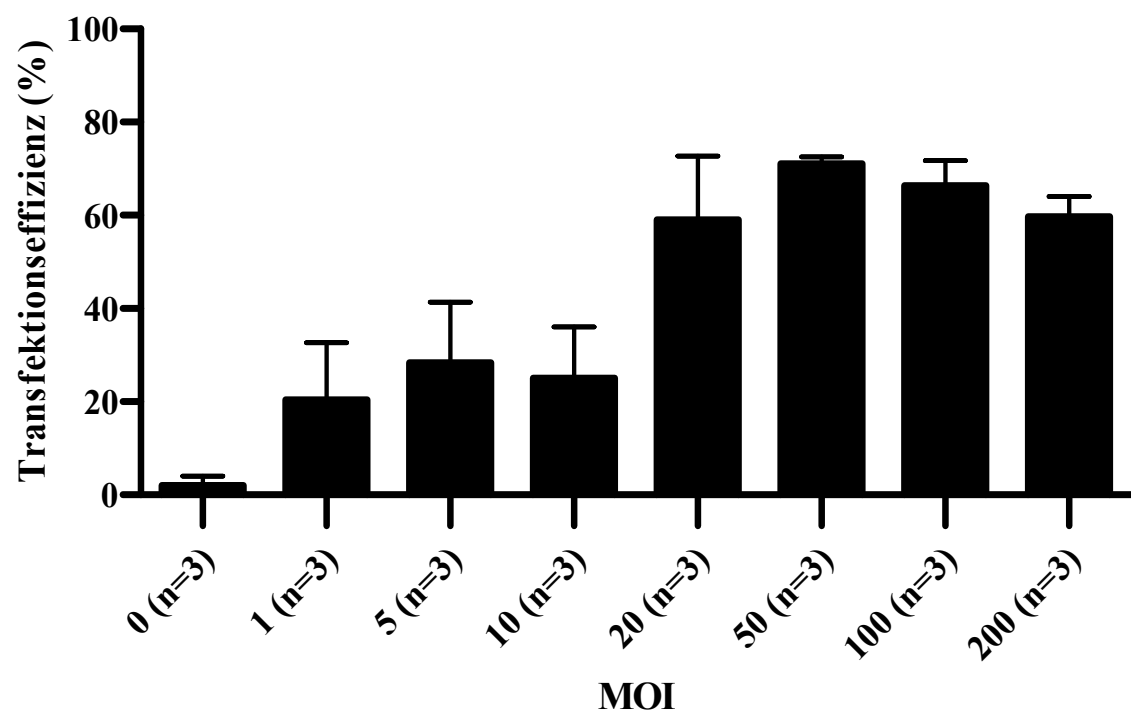

Abb. 7:

Dargestellt ist die Transfektionseffizienz abhängig von der Virus-MOI für

a) adulte Kardiomyozyten. b)

neonatale

Kardio-

myozyten

\subsubsection{Verifizierung der nls-MLP-Expression mittels Western Blot}

Die Expression des durch das nls-MLP-Virus kodierten nukleären MLP wurde an adulten Rattenkardiomyozyten aus drei verschiedenen Isolationen untersucht. Die adulten Kardiomyozyten waren mit aufsteigenden MOI des nls-MLP-Virus transfiziert worden, 
und wurden nach 24 Stunden geerntet und lysiert. Für die spezifische Detektion des nukleären und nicht auch des endogenen MLP wurde ein gegen die HA-Sequenz gerichteter Antikörper verwendet. Es zeigte sich eine deutliche Bande zwischen der 24 kDund der 25 kD-Markierung ab einer MOI von 50 (Abb. 8a)). Das nls-MLP besitzt gegenüber dem endogenen MLP außer dem NLS noch einen zusätzlichen HA-Marker, sodass es im SDS-Gel zwischen $24 \mathrm{kD}$ und $25 \mathrm{kD}$ läuft, während endogenes MLP bei etwa $20 \mathrm{kD}$ läuft. Um die Menge des natürlich in der Zelle vorhandenen MLP mit der des nlsMLP zu vergleichen, wurde ein MLP-Antikörper für die Detektion des gesamten MLP verwendet. Es zeigte sich schon bei geringen Virusmengen eine Bande bei $20 \mathrm{kD}$. Eine zusätzliche Bande zwischen 24 und $25 \mathrm{kD}$, welche das nls-MLP anzeigte, trat jedoch erst ab einer MOI von 50 auf. Das Verhältnis des überexprimierten nls-MLP zu endogenem MLP lag hier bei 1,56:1 (2,06 $\pm 0,32 \mathrm{im}$ Vergleich zu 1,24 $\pm 0,07$, siehe Abb. 8b)). Bei einer MOI von 50 konnte eine ausreichende Expression des nls-MLP bei guter Transfektionseffizienz und noch nicht ausgeprägter Schädigung der Zellen durch die Adenoviren gezeigt werden, sodass alle weiteren Experimente mit dieser Virusmenge pro Zelle durchgeführt wurden.

a)

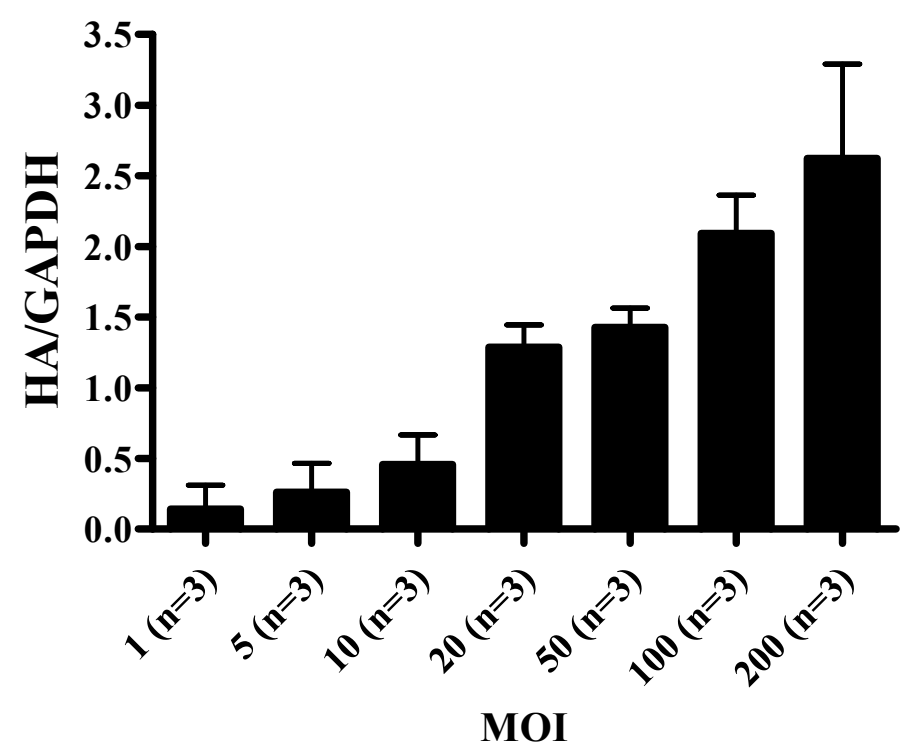

Abb. 8

MLP-Nachweis im

Western Blot normalisiert

auf GAPDH in

Abhängigkeit von der

Virus-MOI.

a) Nachweis des $n l s-M L P$ mittels HA-Antikörper 
b)

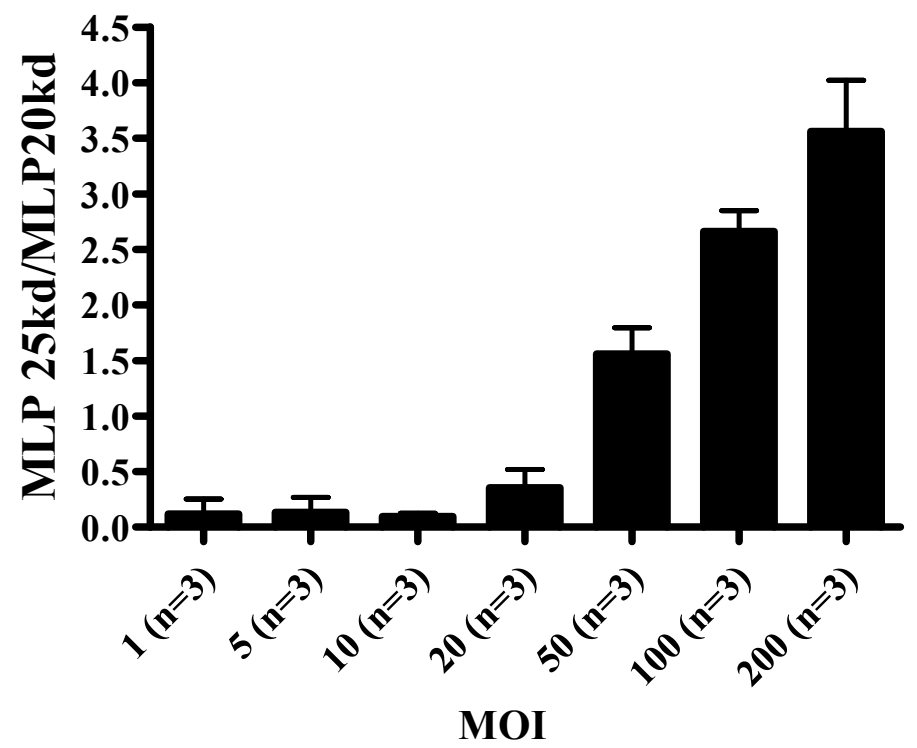

b) Nachweis des gesamten MLP mittels MLP-Antikörper

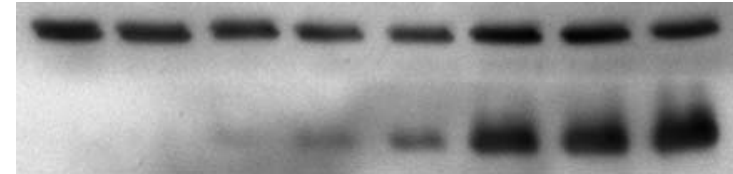

GAPDH Abb. 9

HA

Oben: exemplarischer Blot mit dem HAAntikörper

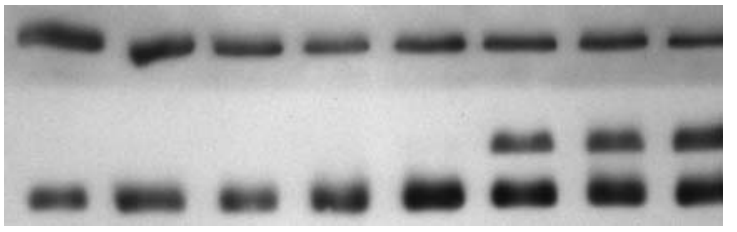

GAPDH Unten: exemplarischer

$\begin{array}{lllllllll}\text { MOI } & 0 & 1 & 5 & 10 & 20 & 50 & 100 & 200\end{array}$ Blot mit dem MLPAntikörper Aufgetragen sind von MLP links nach rechts die MOI 0,1,5,10,20,50,100 und 200 .

\subsubsection{Immunzytochemische Färbung zur Lokalisation des Virus}

Um sicherzustellen, dass die Lokalisation des überexprimierten nls-MLP ausschließlich auf den Zellkern beschränkt war, wurde eine immunzytochemische Färbung durchgeführt. Mit dem nls-MLP-Virus transfizierte adulte Rattenkardiomyozyten aus zwei verschiedenen Isolationen wurden fixiert, und jeweils ein Teil der Zellen mit dem HA- oder dem MLPAntikörper inkubiert. Zusätzlich erfolgte die Färbung der Zellkerne mit DAPI. Während der MLP-Antikörper sowohl zytoplasmatisches wie auch nukleäres MLP detektierte, konnte in der für das nls-MLP spezifischen HA-Färbung die ausschließlich nukleäre Lokalisation gezeigt werden. 


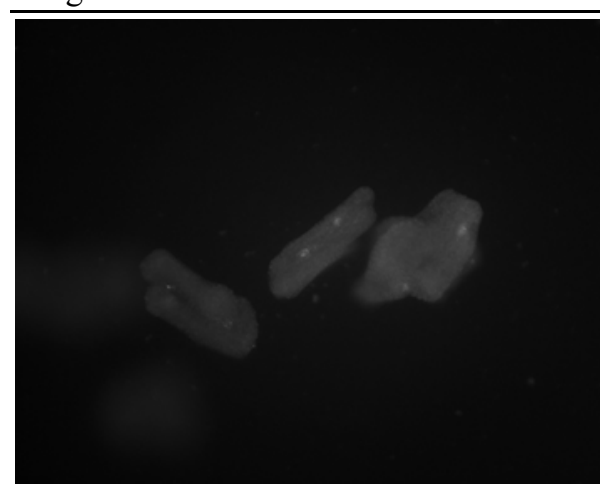

\begin{abstract}
Abb. 10
HA-Färbung: Die HA-Färbung detektiert das nls-MLP an seinem HA-Marker ausschließlich in den Zellkernen der adulten Kardiomyozyten.
\end{abstract}

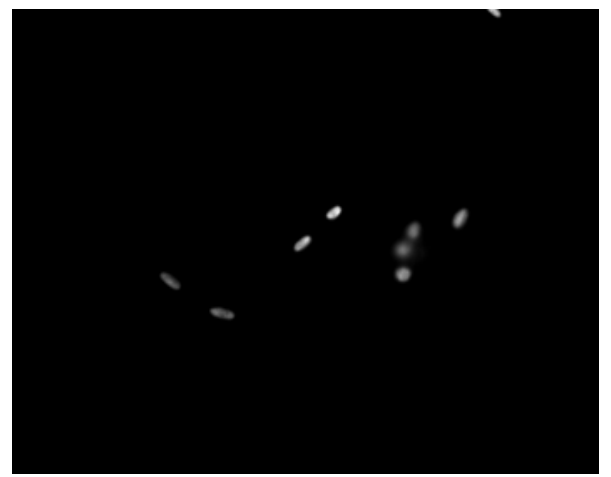

\author{
Abb. 11 \\ DAPI-Färbung: Kontrollfärbung zur \\ Lokalisation der Zellkerne.
}

\title{
4.4 Untersuchung von Kardiomyozyten auf Hypertrophie-Merkmale nach Transfektion mit dem nls-MLP-Virus
}

Um die Hypothese zu prüfen, dass nukleäres MLP eine Hypertrophie hervorrufen kann, wurden mit dem nls-MLP-Virus transfizierte adulte und neonatale Rattenkardiomyozyten auf das Auftreten von Charakteristika der Zellhypertrophie untersucht.

\subsubsection{Planimetrie}

Um eine Größenänderung durch nls-MLP oder endogenes MLP zu überprüfen, wurden neonatale Kardiomyozyten aus zwei verschiedenen Isolationen mit nls-MLP-, nls-LacZoder flag-MLP-Viren transfiziert und nach 48 Stunden Kultur eine Messung der Zellfläche vorgenommen. Als Positivkontrolle dienten mit Phenylephrin stimulierte Zellen, welche im Vergleich zu den nls-LacZ-transfizierten Zellen eine signifikante Größenzunahme um 29,27\% aufwiesen $(1,27 \pm 0,031$, jeweils $n=3, p<0,001)$. Mit dem nls-MLP-Virus oder dem flag-MLP-Virus transfizierte Zellen zeigten keine signifikante Größenänderung im Vergleich zu den mit dem nls-LacZ-Virus transfizierten Kontrollzellen. Um die Möglichkeit zu prüfen, dass nls-MLP nur in Anwesenheit anderer Hypertrophiestimuli Einfluss auf die Entstehung einer Hypertrophie nehmen kann, wurde auch der Effekt von nls-MLP auf die von Phenylephrin hervorgerufenen Hypertrophie untersucht. Es zeigte sich 
kein zusätzlicher Effekt von nls-MLP auf die Größenzunahme der Zellen nach zusätzlicher Stimulation mit Phenylephrin (Daten nicht dargestellt). Somit konnte keine signifikante Änderung der Zellgröße durch Überexpression des nukleären MLP gezeigt werden.

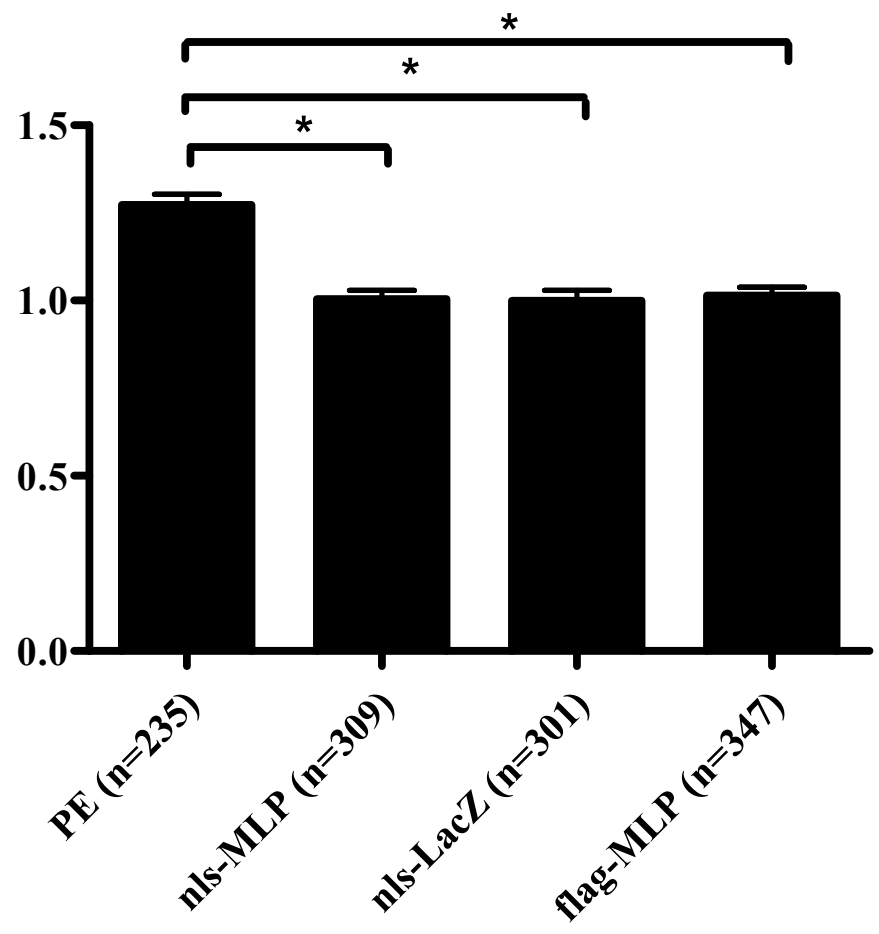

Abb. 12

Verhältnis der mittleren Zell-größen: Die PEstimulierten Zellen zeigten eine signifikante Größenzunahme im Vergleich zu den $n l s-$ LacZ-, flag-MLP- und $n l s-M L P$ überexprimierenden Zellen (jeweils $p<0,001)$, Die transfizierten Zellen zeigten keine Größenänderung.

\subsubsection{Analyse der Expression von ANF, BNP und $\beta$-MHC}

Die mRNA-Expression verschiedener Hypertrophiemarker wurde in mit dem nls-MLPVirus transfizierten adulten Rattenkardiomyozyten aus fünf verschiedenen Isolationen mit der Expression in Kardiomyozyten nach Transfektion mit dem nls-LacZ-Virus verglichen. In der RT-PCR wurde GAPDH als internes Kontrollgen verwendet und die Expression von ANF, BNP und $\beta$-MHC bestimmt. Bei allen drei untersuchten Proteinen zeigten sich keine signifikanten Unterschiede der Expression im Vergleich der beiden Gruppen. Die Mittelwerte betrugen für ANF 1,75 $\pm 0,038$ in den nls-MLP-Virus transfizierten Zellen und $1,87 \pm 0,049$ in den nls-LacZ-Virus transfizierten Zellen $(p=0,84)$, für BNP $0,054 \pm 0,006$ und $0,055 \pm 0,007(\mathrm{p}=0,88)$ und für $\beta$-MHC $0,089 \pm 0,017$ und $0,087 \pm 0,016(p=0,97$; jeweils $n=12$ ). 
a)

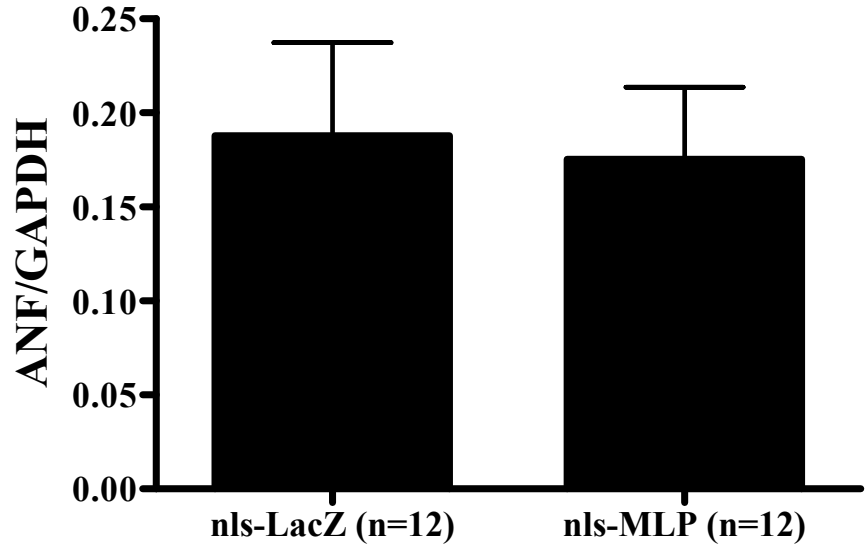

b)

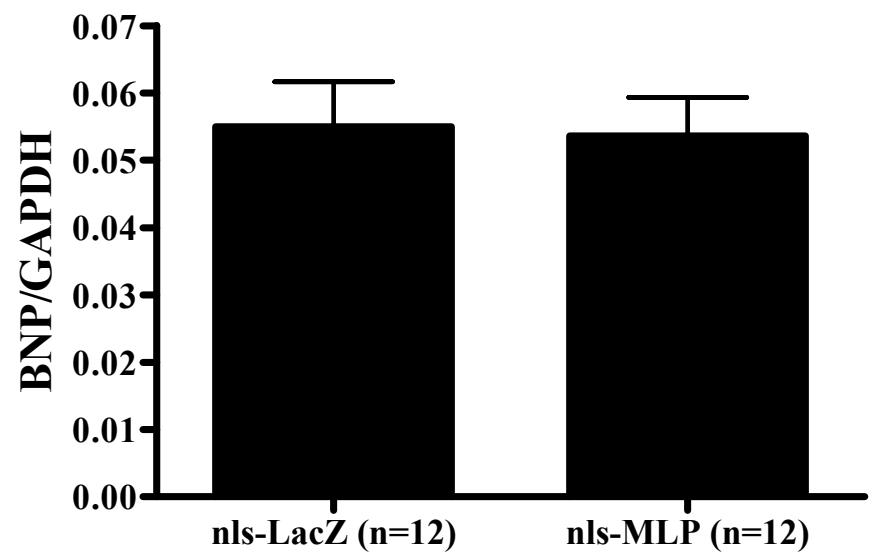

c)

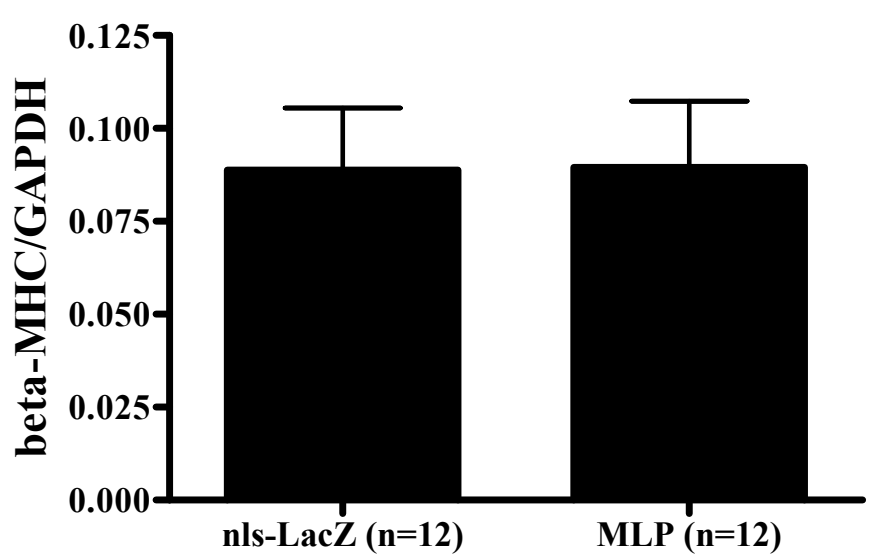

Abb. 13

$m R N A$-Expression in der $R T-P C R$ in nls-MLP- und nls-LacZ-Virus transfizierten Zellen im Vergleich.

a) ANF-Expression $(p=0,84)$

b) BNP-Expression $(p=0,88)$ c) $\beta$-MHC-Expression $(p=0,97)$ 
4.4.3 Autoradiographische Untersuchung auf eine veränderte Proteinsynthese anhand der Inkorporation von $\left[{ }^{3} \mathrm{H}\right]-$ Leucin

Anhand der Inkorporation der mit Tritium radioaktiv markierten Aminosäure $\left[{ }^{3} \mathrm{H}\right]$-Leucin wurde das Maß der Proteinsynthese in adulten Rattenkardiomyozyten aus zwei verschiedenen Isolationen untersucht. Die Zellen wurden mit dem nls-MLP-Virus und in der Kontrollgruppe mit dem nls-LacZ-Virus transfiziert. 4 Stunden nach radioaktiver Markierung wurde die Lichtemission im Szintillationszähler der zuvor mit Szintillationsmolekülen versehenen Proben gemessen. Die Proteinsynthese in den nls-MLP überexprimierenden Zellen stellte sich als signifikant geringer dar im Vergleich zu der Proteinsynthese in den Kontrollzellen (Mittelwerte 1969,42 \pm 168,49 Zerfälle pro Minute, und 2839,55 $\pm 297,99$ Zerfälle pro Minute, jeweils $n=6, p=0,044)$.

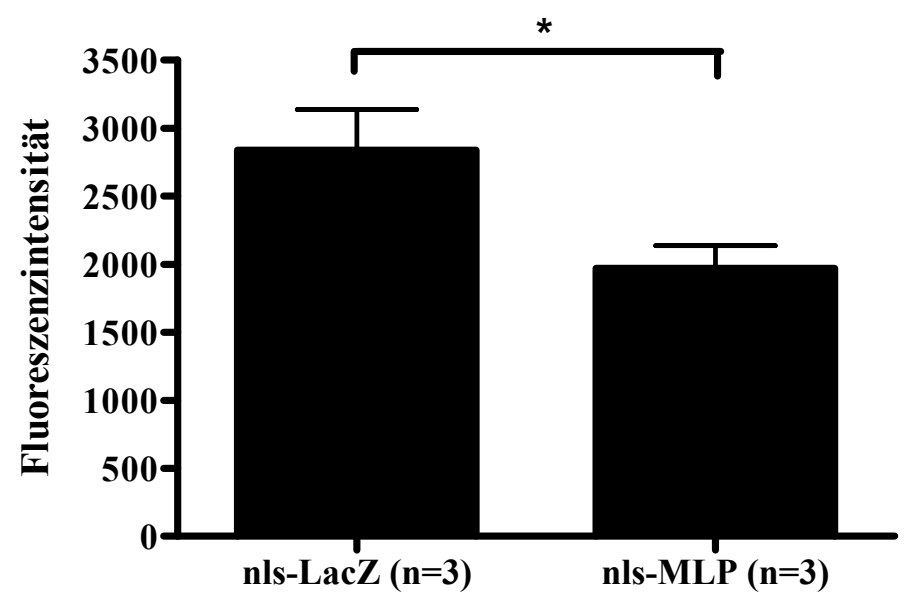
Abb. 14
[HH]-Leucin-Inkorporation in nls-LacZ- und nls-MLP-Virus- transfizierten Zellen im Vergleich $(p=0,044)$. 


\section{Diskussion}

\subsection{Nukleäre Relokalisation und Expression von MLP in der Herzmuskelhypertrophie}

Das Muscle LIM Protein oder CRP3 wurde in Herzmuskelzellen bereits in verschiedenen subzellulären Lokalisationen beschrieben. Es ist vor allem als ein zytoplasmatisches Protein in Assoziation zu Zytoskelettelementen bekannt (Ehler et al. 2001; Flick und Konieczny 2000; Gupta et al. 2008; Heineke et al. 2005). Bei einer vermehrten Herzbelastung wurde jedoch eine veränderte Lokalisation von MLP mit seiner Anreicherung im Zellkern von Kardiomyozyten beobachtet. In hypertrophierten rechten Ventrikeln nach Monocrotaline-Injektion in Ratten zeigten Ecarnot-Laubriet et al. (2000) anhand von immunhistochemischen Analysen eine nukleäre Relokalisation von MLP. Nach 48 Stunden zyklischer Dehnung konnte MLP in neonatalen Kardiomyozyten ebenfalls vermehrt in den Zellkernen nachgewiesen werden (Boateng et al. 2006). In der vorliegenden Arbeit wurde eine vorwiegend nukleäre Lokalisation von MLP zum ersten Mal auch nach Koronarligatur in Mäuseherzen gezeigt. Aus diesen Daten lässt sich schließen, dass völlig unterschiedliche Mehrbelastungen des Herzens in unterschiedlichen Spezies eine nukleäre Relokalisation des Muscle LIM Proteins in Herzmuskelzellen bewirken können. Die Relokalisation von MLP scheint demnach ein fester Bestandteil der Anpassungsreaktion des Herzens auf eine vermehrte Belastung zu sein. Zudem scheint die Relokalisation zu einem bestimmten Zeitpunkt in der Hypertrophie-Antwort des Herzens aufzutreten. In den Versuchen von Ecarnot-Laubriet et al. (2000) trat eine signifikante Hypertrophie der rechten Ventrikel drei Wochen nach Monocrotaline-Injektion zeitgleich mit der veränderten nukleären Lokalisation von MLP auf. Die Koronarligatur als ein Modell für den Myokardinfarkt führt sehr viel früher zu einer signifikanten Hypertrophie. In den Mäuseherzen waren Merkmale der Hypertrophie entsprechend bereits nach drei Tagen nachweisbar. Die Anreicherung von MLP in den Zellkernen trat ebenfalls zu diesem frühen Zeitpunkt auf.

In den Infarktherzen konnte anhand von Paraffinschnitten zu unterschiedlichen Zeitpunkten nach Koronarligatur auch die zeitliche Begrenzung dieser nukleären Relokalisation 
dargestellt werden. Zwei Wochen nach Infarkt war der nukleäre MLP-Nachweis bereits rückläufig und nach acht Wochen war MLP in den Zellkernen nicht mehr nachweisbar. Die nukleäre Relokalisation von MLP scheint demnach vor allem im Rahmen der akuten Anpassung des Herzens an eine Belastung für einen begrenzten Zeitraum aufzutreten. In späteren Stadien der Insuffizienz ließ sich bislang kein nukleäres MLP nachweisen. Dies bestätigten auch die Ergebnisse von Zolk et al. (2000), die zeigten, dass MLP in den explantierten menschlichen Herzen von Patienten in den Endstadien der Herzinsuffizienz ausschließlich zytoplasmatisch vorhanden war.

Es stellt sich die Frage, ob das nukleäre MLP aus einer bekannten Lokalisation im Zytoplasma in den Zellkern transloziert oder aber, ob neues MLP nukleär exprimiert wird. Auch eine Kombination beider Mechanismen ist denkbar. Die Regulation der Expression von MLP scheint mit der Herzmuskelhypertrophie im Zusammenhang zu stehen. In vitro konnte eine vermehrte Expression von MLP in hypertrophierenden Kardiomyozyten nach Applikation von Endothelin sowie eine verminderte Expression von MLP durch das antihypertroph wirkende NO gezeigt werden (Heineke et al. 2003). Auch in vivo wurde bereits mehrfach eine veränderte Expression von MLP in der Hypertrophie beschrieben. In Rattenherzen zeigten Wilding et al. (2005) 10 Wochen nach Infarkt eine erhöhte MLPExpression, die negativ mit der Ejektionsfraktion der Herzen korrelierte. Boateng et al. (2006) konnten eine Zunahme der Expression von MLP 6 Monate nach Infarkt und auch nach Aortenligatur zeigen. In der vorliegenden Arbeit wurde die Expression von MLP in den Infarktherzen ebenfalls untersucht. Es zeigte sich nach zwei Wochen eine durchschnittlich um $46 \%$ gesteigerte MLP-Expression auf mRNA-Ebene. Dieses Ergebnis war aufgrund von starken Schwankungen in den Präparaten jedoch nicht signifikant. Nach drei Monaten hatte sich auch auf mRNA-Ebene kein Unterschied mehr dargestellt. Zu diesen Zeitpunkten nach Infarkt zeigte sich in den Mäuseherzen somit keine veränderte Expression.

Im Rahmen des CardioGenomics-Projektes der Harvard Medical School wurden online unter anderem die Ergebnisse der Genchip-Analysen in Mäuseherzen nach aortic banding veröffentlicht. Die veränderte Expression von MLP in diesen Versuchen, deren graphische Auswertung anhand der online-Daten erstellt und unten abgebildet ist, zeigt einen ähnlichen zeitlichen Verlauf wie die nukleäre Relokalisation von MLP in den Infarktherzen. Der stärkste Anstieg der Expression von MLP war bereits nach 24 Stunden aufgetreten. $\mathrm{Zu}$ späteren Zeitpunkten nahm die Expression wieder deutlich ab. 
Möglicherweise hätte sich analog $\mathrm{zu}$ den Daten nach aortic banding auch in den Infarktherzen zu einem früheren Zeitpunkt eine erhöhte Expression von MLP zeigen lassen, als auch die nukleäre Relokalisation von MLP aufgetreten war.

\section{Cardiogenomics-Genchipanalysen: MLP nach aortic banding}

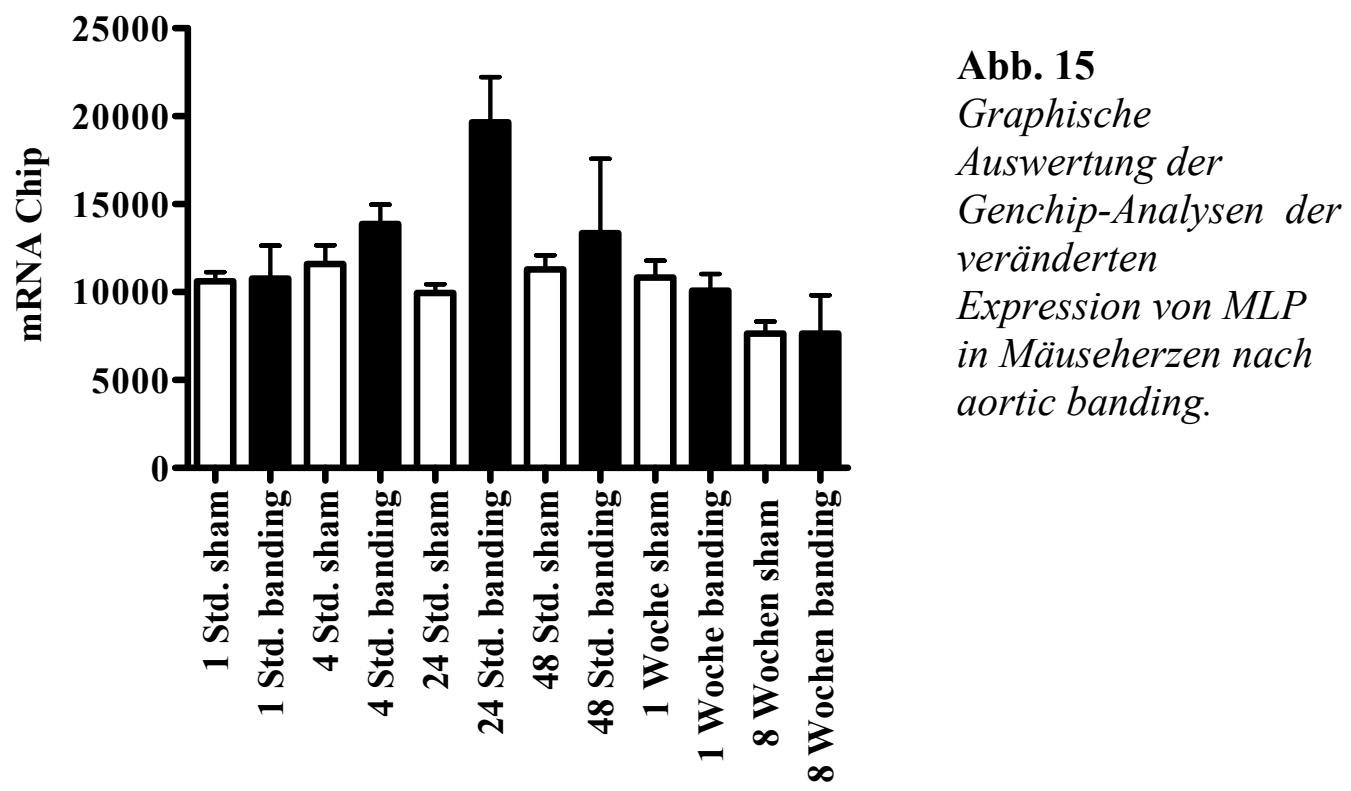

In den Infarktherzen konnte MLP nur in einem begrenzten Bereich im Infarktrandgebiet in den Zellkernen nachgewiesen werden. Denkbar ist demnach auch eine Änderung seiner Expression nur in den betroffenen Teilen des Ventrikels. Somit sind die Analysen aus ganzen Ventrikeln besonders nach Entfernung der Infarktnarbe zusammen mit dem Infarktrandgebiet möglicherweise nicht aussagekräftig. Dies könnte die unterschiedlichen Ergebnisse der Expressionsanalysen nach Infarkt erklären, ist aber auf andere Hypertrophie-Modelle nur schwer zu übertragen.

Auch eine signifikant verminderte Expression von MLP in der Hypertrophie wurde bereits beschrieben. In den Monocrotaline-behandelten Ratten ging die nukleäre Relokalisation mit einer verminderten MLP-Expression und deutlich geringerer zytoplasmatischer MLPDetektion einher (Ecarnot-Laubriet et al. 2000). Diese Ergebnisse können als ein Hinweis auf eine Translokation von MLP aus einer zytoplasmatischen Lokalisation in den Zellkern verstanden werden. Zolk et al. (2000) hatten ebenfalls eine signifikant erniedrigte Expression von MLP in den insuffizienten Herzen gezeigt. Einige seiner Patienten hatten jedoch eine langjährige Therapie mit Nitraten erhalten, sodass eine verminderte Expression von MLP auch auf diese Weise hervorgerufen sein kann, da NO als ein negativer Regulator der MLP-Expression fungiert (Heineke et al. 2003). 
Unterschiede in den Genexpressionsmustern nach verschiedenartigen Belastungen - vor allem aber nach Druck- und Volumenbelastung - wurden bereits gezeigt (Janssen et al. 2002; Toischer et al. 2008). Eine uneinheitliche Regulation der Expression von MLP nach unterschiedlichen Belastungen erscheint also ebenfalls möglich. Auch die Stärke der Belastung und das Ausmaß der resultierenden Insuffizienz könnten Einfluss auf die Änderung der Expression von MLP nehmen. Eine direkte Korrelation der vermehrten Expression von MLP mit einer sinkenden Ejektionsfraktion konnte bereits gezeigt werden (Wilding et al. 2005). Nicht zuletzt müssen auch mögliche Unterschiede in der Genexpression zwischen den drei untersuchten Spezies Maus, Ratte und Mensch in die Überlegungen mit einbezogen werden.

Zusammenfassend lässt sich sagen, dass unterschiedliche Arten der Belastung des Herzens zwar eine vermehrt nukleäre Lokalisation von MLP in Kardiomyozyten bewirken können, eine Änderung der Expression des MLP in der Hypertrophie jedoch nicht einheitlich ist. Demnach ist auch die Herkunft des nukleären MLP innerhalb der Kardiomyozyten weiterhin zu klären. Die Regulation der Expression von MLP in unterschiedlichen Formen der Herzbelastung erscheint komplex und wird weitere Untersuchungen erfordern.

\subsection{Funktion von MLP im Zellkern}

Die nukleäre Relokalisation von MLP in der Herzmuskelhypertrophie ist ein Hinweis auf eine mögliche Funktion von nukleärem MLP in der Regulation der Hypertrophie-Antwort des Herzens. Für LIM-only-Proteine wie MLP wird seit längerem angenommen, dass sie die Fähigkeit besitzen, zwischen Zytoplasma und Zellkern zu translozieren und im Zellkern als potentielle Transkriptionsfaktoren oder Kofaktoren $\mathrm{zu}$ fungieren (Benmerah et al. 2003). MLP besitzt ein nukleäres Lokalisierungssignal, dessen Funktion vor kurzem gezeigt werden konnte (Boateng et al. 2009). Die Beeinflussung der Genexpression sowie eine Interaktion von MLP mit den Transkriptionsfaktoren der MyoD-Familie konnte für nukleäres nls-MLP im Zellkern von Skelettmuskelzellen bereits gezeigt werden (Kong et al. 1997). Das Vorhandensein von nukleärem MLP war außerdem notwendig für die Differenzierung myogener Zellen und die Ausbildung ihres Zytoskeletts (Arber et al. 1994). Sogar einen direkt Hypertrophie-induzierenden Effekt von MLP in Kardiomyozyten konnten Heineke et al. (2003) durch MLP-Überexpression bereits zeigen.

In der vorliegenden Arbeit wurde auf Grundlage der vorgestellten Daten die Hypothese aufgestellt, dass nukleäres MLP im Zellkern von Kardiomyozyten Einfluss auf die 
Genregulation nimmt und in Kardiomyozyten Hypertrophie-Merkmale induzieren kann. Diese These wurde untersucht, indem mit Hilfe eines viralen Vektors vorwiegend nukleär lokalisiertes nls-MLP in Kardiomyozyten überexprimiert und die transfizierten Kardiomyozyten auf Zeichen einer Hypertrophie untersucht wurden. Die regelrechte Funktion des nls-MLP-Virus wurde mittels Immunfärbungen und Western-Blot-Analysen getestet, und sowohl die deutliche Überexpression als auch die nukleäre Lokalisation des nls-MLP in den transfizierten Kardiomyozyten konnten gezeigt werden.

Zunächst wurde eine Änderung der Zellgröße durch den Einfluss von nukleärem MLP als Charakteristikum einer Hypertrophie untersucht. Nach mehrtägiger Kultur der mit dem nlsMLP-Virus transfizierten neonatalen Kardiomyozyten wurden Zellumfangsmessungen durchgeführt. In den nls-MLP überexprimierenden Kardiomyozyten zeigte sich keine signifikante Änderung der Zellgröße im Vergleich zu den mit dem nls-LacZ-Virus transfizierten Zellen. Da die Zellen in einer Vergleichsgruppe auf die Stimulation mit Phenylephrin mit signifikanter Größenzunahme reagierten, kann von der Stimulierbarkeit der Zellen ausgegangen und ein methodischer Fehler weitgehend ausgeschlossen werden. In den Veröffentlichungen von Heinecke et al. war MLP ohne eine bestimmte subzelluläre Lokalisation überexprimiert worden. Um den Einfluss von zytoplasmatischem MLP mit dem des nls-MLP auf die Zellgröße direkt vergleichen zu können, wurde die Transfektion der Kardiomyozyten mit einem flag-MLP-Virus durchgeführt und ebenfalls die Zellgrößen gemessen. Auch durch die Überexpression des zytoplasmatischem MLP konnte keine Zellgrößenzunahme der Kardiomyozyten erreicht werden. Somit kann die fehlende Größenzunahme nach nls-MLP-Expression nicht dadurch erklärt werden, dass es sich um einen zytoplasmatischen Effekt handelt. Vielmehr zeigen diese Ergebnisse, dass der beschriebene Hypertrophie-auslösende Effekt von MLP nicht jederzeit reproduzierbar ist. Möglicherweise sind aber auch bestimmte Bedingungen entscheidend für einen eindeutigen Effekt von MLP. Arber et el. (1994) hatten beschrieben, dass eine messbare Vergrößerung der Zytoskelettelemente und vemehrte MHC-Expression nach MLP-Überexpression in myogenen Zellen stark von einer bestimmten Serumkonzentration abhing. Außerdem konnte bei zu starker Überexpression keine Differenzierung der Zellen mehr stattfinden. Mit den in dieser Arbeit beschriebenen Versuchsbedingungen konnten die Ergebnisse von Heineke et al. (2003) nicht nachvollzogen werden.

Eine vermehrte Expression von MLP und seine nukleäre Lokalisation wurden mehrfach im Zusammenhang zu signifikant veränderten Expressionsraten der Hypertrophie- 
Markerproteine ANF, BNP und $\beta$-MHC beschrieben (Arber et al. 1994; Boateng et al. 2006; Wilding et al. 2005). Da MLP keine eigene DNA-Bindungsstelle aufweist, muss es für einen Einfluss von MLP auf die Genexpression Bindungspartner im Zellkern geben. Die dem MLP verwandten Proteine CRP1 und CRP2 wirken in glatten Muskelzellen als Transkriptionsfaktoren und interagieren dort über ihre LIM-Domänen mit einem Komplex aus GATA-Faktoren und SRF. Auf diese Weise beeinflussen sie die Genexpression von für glatte Muskelzellen spezifischen Proteinen (Chang et al. 2003). Ein ähnlicher Mechanismus wäre auch für MLP denkbar, da auch MLP in den Versuchen von Chang et al. (2003) eine -wenngleich schwächere- Aktivierung der Genexpression durch die Interaktion mit GATA4 und SRF über seine LIM-Domänen gezeigt hat. GATA4 ist der im Herzen dominierende GATA-Faktor und ist unter anderem an der Regulation von mit Hypertrophie assoziierten Genen wie z.B. der Hypertrophie-Marker ANF und BNP beteiligt (Charron et al. 1999). Auch eine Interaktion von GATA4 und SRF sowie die gemeinsame Regulation der Genexpression in Herzmuskelzellen konnte bereits gezeigt werden (Belaguli et al. 2000). MLP könnte demnach im Herzen analog zu CRP1 und CRP2 über seine LIM-Domänen die DNA-Bindung des Komplexes aus GATA4 und SRF stabilisieren. In den vorgestellten Versuchen wurden die Expressionsraten der drei Hypertrophie-Marker ANF, BNP und $\beta$-MHC in nls-MLP überexprimierenden Kardiomyozyten untersucht. In diesen Zellen konnte auf mRNA-Ebene keine Änderung der Expression der drei Proteine im Vergleich zu ihrer Expression in den Kontrollzellen festgestellt werden. Es ist denkbar, dass in den durchgeführten Versuchen das dem MLP zugefügte nukleäre Lokalisierungssignal eine Bindung von MLP an den GATA4-SRFKomplex verhindert hat. Kong et al. (1997) hatten jedoch eine Interaktion dieses nls-MLP mit Transkriptionsfaktoren der MyoD-Familie zeigen können, was einen störenden Effekt des nls auf die Bindung $\mathrm{zu}$ Transkriptionsfaktoren eher unwahrscheinlich macht. Möglicherweise ist aber die alleinige Überexpression von MLP im Zellkern nicht ausreichend, um eine Änderung der Transkriptionsraten der Marker-Proteine zu erzielen. Bei der Untersuchung eines weiteren LIM-Proteins im Herzen, dem hhLIM (human heart LIM), konnten Zheng B et al. (2008) erst nach gemeinsamer Überexpression von hhLIM und Nkx2.5 einen Anstieg der ANF-Expression zeigen. Die alleinige Überexpression von hhLIM hatte nicht zu veränderter Expression führen können (Zheng et al. 2008). Wenngleich auch andere Bindungspartner von MLP im Zellkern denkbar sind, kann die Interaktion von MLP und GATA4 durch die alleinige Untersuchung der Expressionsraten 
der ausgewählten Proteine nicht ausgeschlossen werden. Die Regulation der Expression von $\alpha$-Aktinin, einem Zytoskelettelement, durch den Komplex aus GATA4 und SRF wurde bereits gezeigt (Belaguli et al. 2000). Mehrere Arbeitsgruppen konnten bereits eine deutliche Vermehrung von Zytoskelettelementen durch MLP-Überexpression und kürzlich sogar die Abhängigkeit von nukleärem MLP zeigen (Arber et al. 1994; Boateng et al. 2009; Heineke et al. 2003). MLP könnte also möglicherweise über den GATA4-SRF-Komplex Einfluss auf die Expression von Zytoskelettelementen in der Herzmuskelhypertrophie nehmen.

Als ein weiteres Merkmal der Hypertrophie in Kardiomyozyten wurde in dieser Arbeit die Proteinsyntheserate nach Überexpression von nls-MLP untersucht. Die Messung der Proteinsynthese in den adulten Kardiomyozyten erfolgte indirekt anhand ihrer Aufnahme der radioaktiv markierten Aminosäure [ $\left.{ }^{3} \mathrm{H}\right]$-Leucin (Jacobshagen et al. 2007). Es kam zu einer signifikant geringeren Proteinsynthese in nls-MLP-überexprimierenden Zellen im Vergleich zu den mit dem nls-Lac-Z-Virus transfizierten Zellen. Auch nach flag-MLPÜberexpression war die Proteinsyntheserate signifikant erniedrigt (Daten nicht gezeigt). Im Gegensatz dazu hatten Heineke et al. (2003) zuvor eine signifikante Zunahme der Proteinsynthese nach MLP-Überexpression ebenfalls durch Messung der Aufnahme von $\left[{ }^{3} \mathrm{H}\right]$-Leucin zeigen können. In weiteren kürzlich veröffentlichten Ergebnissen zeigen Boateng et al. (2009), dass eine gesteigerte Proteinsynthese in der Hypertrophie sogar das Vorhandensein von nukleärem MLP voraussetzte. Eine denkbare Erklärung für die Abnahme der Proteinsynthese durch nls-MLP-Überexpression wäre eine stärkere Schädigung der Zellen durch das nls-MLP-Virus im Vergleich zum nls-LacZ-Virus. Jedoch hatte auch die flag-MLP-Überexpression dasselbe Ergebnis gezeigt. Boateng et al. (2009) unterschieden eine oligomere zytoplasmatische und eine monomere nukleäre Form des MLP. Sie mutmaßten, dass eine virale Überexpression von MLP die Oligomerisation verhindern und MLP somit in seiner Funktion beeinträchtigen könnte.

Die Ergebnisse dieser Arbeit zeigen, dass die alleinige Anwesenheit von MLP im Zellkern nicht ausreichend für die Induktion einer Hypertrophie in Kardiomyozyten ist, wobei ein Einfluss auf das Zytoskelett nicht untersucht wurde. Eine mögliche Ursache für die ausbleibenden Effekte des nls-MLP könnte die Methode der viralen Überexpression sein, wie Boateng et al. (2009) argumentierten. Ebenfalls ist es denkbar, dass für die Regulation der Hypertrophie durch nukleäres MLP weitere Faktoren notwendig sind, die in den hier beschriebenen Experimenten nicht zusätzlich überexprimiert oder zugesetzt wurden. Ein 
Einfluss von nukleärem MLP auf die Genregulation in der Hypertrophie ist aufgrund der gezeigten nukleären Relokalisation sowie der bereits in der Literatur beschriebenen Funktionen von MLP weiterhin anzunehmen. Mit welchen Bindungspartnern MLP im Zellkern der Herzmuskelzellen interagiert und welche Gene MLP-abhängig reguliert werden könnten, muss also weitergehend untersucht werden.

\subsection{Schlussfolgerung und Ausblick}

In der vorliegenden Arbeit wurde zum ersten Mal auch nach Infarkt die nukleäre Relokalisation des Muscle LIM Proteins in der Herzmuskelhypertrophie gezeigt. Da nun bereits in unterschiedlichen Modellen der vermehrten Herzbelastung die nukleäre Relokalisation von MLP gezeigt werden konnte, scheint MLP in Herzmuskelzellen eine weitere nukleäre Funktion in der Hypertrophie zu besitzen. Die Regulation der Expression von MLP in der Hypertrophie erscheint komplex und sollte weiterführend untersucht werden. Ebenso muss die Rolle von nukleärem MLP in der Hypertrophie aufgeklärt werden. Kann eine regulierende Funktion von nukleärem MLP in der HypertrophieAntwort des Herzens bestätigt werden, könnten MLP oder seine potentiellen Bindungspartner ein weiteres mögliches Ziel künftiger therapeutischer Interventionen in der Prävention von Herzversagen darstellen. 


\section{$6 \quad$ Zusammenfassung}

In verschiedenen pathologischen Zuständen des Herzens wurde bereits eine vermehrt nukleäre Lokalisation des bislang vornehmlich als Zytoskelett-Protein bekannten MLP beobachtet. In der vorliegenden Arbeit wurde die Lokalisation sowie die Expression von MLP nach Koronarligatur als einem Modell für den Myokardinfarkt untersucht. Es konnte erstmals auch in diesem Modell eine vermehrt nukleäre Lokalisation von MLP gezeigt werden. Zwei Tage nach Koronarligatur trat die Anreicherung von MLP in den Zellkernen auf. Zu diesem Zeitpunkt begannen die Herzen, Hypertrophie-Merkmale auszubilden. Die nukleäre Lokalisation von MLP zeigte sich des Weiteren nur in einem umschriebenen Bereich im Infarktrandgebiet und war nur etwa zwei Wochen lang nachweisbar. Es konnte demnach gezeigt werden, dass MLP in akuter Belastung des Herzens in der beginnenden Hypertrophie der Herzen für einen bestimmten Zeitraum nukleär relokalisiert. Die Expression von MLP war nach Infarkt nicht signifikant verändert im Vergleich zu seiner Expression in den Sham-Herzen. Auch die bislang veröffentlichten Ergebnisse zeigen keine einheitliche Regulation von MLP in der Herzinsuffizienz.

Um die Funktion des nukleären MLP in der Hypertrophie aufzuklären, wurde in der vorliegenden Arbeit mittels eines viralen Vektors nukleäres nls-MLP in Kardiomyozyten überexprimiert. Die Zellen wurden anschließend auf Hypertrophie-Merkmale untersucht. Durch nls-MLP-Überexpression konnte jedoch keine Hypertrophie in den transfizierten Kardiomyozyten induziert werden. 


\section{$7 \quad$ Literaturverzeichnis}

Arber, S und Caroni, P (1996): Specifity of single LIM motifs in targeting and LIM/LIM interactions in situ. Genes Dev 10(3), 289-300

Arber, S, Halder, G, Caroni, P (1994): Muscle LIM protein, a novel essential regulator of myogenesis, promotes myogenic differentiation. Cell 79(2), 221$\underline{231}$

Arber, S, Hunter, J, Ross Jr, J, Hongo, M, Sansig, G, Borg, J, Perriard, J-C, Chien, K, Caroni, P (1997): MLP-deficient mice exhibit a disruption of cardiac cytoarchitectural organization, dilated cardiomyopathy, and heart failure. Cell $\underline{88(3), 393-403}$

Bach, I (2000): The LIM domain: regulation by association. Mech Dev 91(1-2), 5-17

Belaguli, N, Sepulveda, J, Nigam, V, Charron, F, Nemer, M, Schwartz, R (2000): Cardiac tissue enriched factors Serum Response Factor and GATA-4 are mutual coregulators. Mol Cell Biol 20(20), 7550-7558

Benmerah, A, Scott, M, Poupon, V, Marullo, S (2003): Nuclear functions for plasma membrane-associated proteins? Traffic $\underline{4(503-511}$

Boateng, S, Belin, R, Geenen, D, Margulies, K, Martin, J, Hoshijima, M, de Tombe, P, Russel, B (2006): Cardiac dysfunction and heart failure are associated with abnormalities in the subcellular distribution and amounts of oligomeric muscle LIM protein. Am J Heart Circ Physiol 292(1), H 259-269

Boateng, S, Senyo, S, Qi, L, Goldspink, P, Russell, B (2009): Myocyte remodeling in response to hypertrophic stimuli requires nucleocytoplasmatic shuttling of muscle LIM protein. J Mol Cell Cardiol 474(426-435

Chang, D, Belaguli, N, Iyer, D, Roberts, W, Wu, S, Dong, X, Marx, J, Moore, M, Beckerle, M, Majesky, M, Schwartz, R (2003): Cysteine-rich LIM-only proteins CRP1 and CRP2 are potent smooth muscle differentiation cofactors. Dev Cell 4(1), 107-118

Charron, F, Paradis, P, Bronchain, O, Nemer, G, Nemer, M (1999): Cooperative interaction between GATA-4 und GATA-6 regulates myocardial gene expression. J Mol Cell Cardiol 19(6), 4355-4365

Chien, K, Knowlton, K, Zhu, H, Chien, S (1991): Regulation of cardiac gene expression during myocardial growth and hypertrophy: molecular studies of an adaptive physiologic response. Faseb $\mathrm{J} \underline{\text { 5(15), 3037-3046 }}$

Clerk, A, Cullingford, T, Fuller, S, Giraldo, A, Markou, T, Pikkarainen, S, Sugden, P (2007): Signaling pathways mediating cardiac myocyte gene expression in physiological and stress response. J Cell Physiol 212(2), 311-322

Dawid, I, Breen, J, Toyama, R (1998): LIM domains: multiple roles as adapters and functional modifiers in protein interactions. Trends Genet 14(4), 156-162 
Dorn, G, Robbins, J, Sugden, P (2003): Phenotyping hypertrophy: Eschew obfuscation. Circ Res 92(11), 1171-1175

Ecarnot-Laubriet, A, De Luca, K, Vandroux, D, Moisant, M, Bernard, C, Assem, M, Rochette, L, Teyssier, J (2000): Downregulation and nuclear relocation of MLP during the progression of right ventricular hypertrophy induced by chronic pressure overload. J Mol Cell Cardiol 32(12), 2385-2395

Ehler, E, Horowits, R, Zuppinger, C, Price, R, Perriard, E, Leu, M, Caroni, P, Sussman, M, Eppenberger, H, Perriard, J (2001): Alterations at the Intercalated Disk Associated with the Absence of Muscle LIM Protein. J Cell Biol 153(4), 763-

Flick, M und Konieczny, S (2000): The muscle regulatory and structural protein MLP is a cytoskeletal binding partner of betaI-spectrin. J Cell Sci 113(9), 1553-1564

Frey, N, Katus, H, Olson, E, Hill, J (2004): Hypertrophy of the heart: a new therapeutic target? Circulation 109(13), 1580-1589

Frey, N und Olson, E (2003): Cardiac hypertrophy: the Good, the Bad and the Ugly. Annu Rev Physiol 65(2003), 45-79

Freyd, G, Kim, SK, Horvitz, HR (1990): Novel cysteine-rich motif and homeodomain in the product of the Caenorhabditis elegans cell lineage gene lin-11. Nature $\underline{344(6269), 876-879}$

Geier, C, Perrot, A, Ozcelik, C, Binner, P, Counsell, D, Hoffmann, K, Pilz, B, Martiniak, Y, Gehmlich, K, van der Ven, P, Fürst, D, Vornwald, A, van Hodenberg, A, Nürnberg, P, Scheffold, T, Dietz, R, Osterziel, K (2003): Mutations in the human muscle LIM protein gene in families with hypertrophic cardiomyopathy. Circulation 107(10), 1344-1346

Gupta, M, Samant, S, Smith, S, Shroff, S (2008): HDAC4 and PCAF bind to cardiac sarcomeres and play a role in regulating myofilament contractile activity. $J$ Biol Chem 283(15), 10135-10146

Hannan, R, Jenkins, A, Jenkins, A, Brandenburger, Y (2003): Cardiac hypertrophy: a matter of translation. Clin Exp Pharmacol Physiol 30(8), 517-527

Heineke, J, Kempf, T, Kraft, T, Hilfiker, A, Morawietz, H, Scheubel, RJ, aroni, P, ohmann, S, rexler, H, ollert, KC (2003): Downregulation of Cytoskeletal Muscle LIM Protein by Nitric Oxide: Impact on Cardiac Myocyte Hypertrophy. Circulation 107(10), 1424-1432

Heineke, J und Molkentin, J (2006): Regulation of cardiac haypertrophy by intracellular signalling pathways. Nature Reviews $\underline{7(8), 589-600}$

Heineke, J, Ruetten, H, Willenbockel, C, Gross, S, Naguib, M, Schaefer, A, Kempf, T, Hilfiker-Kleiner, D, Caroni, P, Kraft, T (2005): Attenuation of cardiac remodeling after myocardial infarction by muscle LIM protein-calcineurin signaling at the sarcomeric Z-disc. Procl Natl Acad Sci USA 102(5), 1655-1660

Hunter, J und Chien, K (1999): Signaling pathways for cardiac hypertrophy and failure. N Engl J Med 341(17), 1276-1283 
Izumo, S, Nadal-Ginard, B, Mahdavi, V (1988): Protooncogene induction and reprogramming of cardiac gene expression produced by pressure overload. Procl Natl Acad Sci USA 85(2), 339-343

Jacobshagen, C, Grüber, M, Teucher, N, Schmidt, A, Unsöld, B, Toischer, K, Van, P, Maier, L, Kögler, H, Hasenfuss, G (2007): Celecoxib modulates hypertrophic signalling and prevents load-induced cardiac dysfunction. Eur J Heart Fail $\underline{\text { 10(334-342 }}$

Janssen, P, Schillinger, W, Donahue, J, Zeitz, O, Emami, S, Lehnart, S, Weil, J, Eschenhagen, T, Hasenfuss, G, Prestle, J (2002): Intracellular beta-blockade: overexpression of Galpha(i2) depresses the beta-adrenergic response in intact myocardium. Cardiovasc Res $\underline{\text { 55(2), 300-308 }}$

Kannel, W (2000): Vital epidemiologic clues in heart failure. J Clin Epidemiol 53(3), $\underline{\mathbf{2 2 9}-235}$

Karlsson, O, Thor, S, Norberg, T, Ohlsson, H, Edlund, T (1990): Insuline gene enhancer binding protein Isl-1 is a member of a novel class of proteins contaninig both a homeo- and a Cys-His domain. Nature $\underline{344(6269), 879-882}$

Knöll, R, Hoshijima, M, Hoffman, H, Person, V, Lorenzen-Schmidt, I, Bang, M, Hayashi, T, Shiga, N, Yasukawa, H, Schaper, W (2002): The cardiac mechanical stretch sensor machinery involves a Z-disc complex that is defective in a subset, of human dilated cardiomyopathy. Cell 111(7), 943-955

Kong, Y, Flick, MJ, Kudla, AJ, Konieczny, SF (1997): Muscle LIM protein promotes myogenesis by enhancing the activity of MyoD. Mol Cell Biol 17(8), 4750-4760

Laemmli, U (1970): Cleavage of structural proteins during the assembly of the head of bacteriophage T4. Nature $\underline{227(680-685}$

Levy, D, Kenchaiah, S, Larson, M, Benjamin, E, Kupka, M, Ho, K, Murabito, J, Vasan, $R$ (2002): Long-term trends in the incidence of and survival with heart failure. N Engl J Med 347(18), 1397-1402

Louis, H, Pino, J, Schmeichel, K, Pomiès, P, Beckerle, M (1997): Comparision of three members of the Cysteine-rich Protein family reveals functional conservation and divergent patterns of gene expression. J Biol Chem 272(43), 27484-27491

Michael, L, Entman, M, Hartley, C, Youker, K, Zhu, J, Hall, S, Hawkins, H, Berens, $K$, Ballantyne, $C$ (1995): Myocardial ischemia and reperfusion: a murine model. Am J Physiol Heart Circ Physiol 269(6), H2147-H2154

Michelsen, JW, Schmeichel, KL, Beckerle, MC, Winge, DR (1993): The LIM motif is a specific zinc-binding protein domain. Proceedings of the National Academy of Sciences 90(10), 4404-4408

Mohapatra, B, Jimenez, S, Lin, J, Bowles, K, Coveler, K, Marx, J, Chrisco, M, Murphy, R, Lurie, P, Schwartz, R, Elliott, P, Vatta, M, McKenna, W, Towbin, J, Bowles, N (2003): Mutations in the muscle LIM protein and alpha-actinin-2 genes in dilated cardiomyopathy and endocardial fibroelastosis. Mol Genet Metab 80(1-2), 207-215 
Rétaux, S und Bachy, I (2002): A short story of LIM domains (1993-2002): from protein interaction to degradation. Mol Neurobiol 26(2-3), 269-281

Sánchez-García, I und Rabbitts, T (1994): The LIM domain: a new structural motif found in ziny-finger-like proteins. Trends Genet $\underline{10(9), 315-320}$

Toischer, K, Kögler, H, Tenderich, G, Grebe, C, Seidler, T, Van, P, Jung, K, Knöll, R, Körfer, R, Hasenfuss, G (2008): Elevated afterload, neuroendocrine stimulation and human heart failure increase BNP levels and inhibit preloaddependent SERCA upregulatin. Circ Heart Fail 1(4), 265-271

Way, JC und Chalfie, M (1988): mec-3, a homeobox-containing protein gene that specifies differentiation of the touch receptor neurons in C. elegans. Cell 54(1), $\underline{5-16}$

Weiskirchen, R und Günther, K (2003): The CRP/MLP/TLP family of LIM domain proteins: acting by connecting. Bioessays 25(2), 152-162

Weiskirchen, R, Pino, J, Macalma, T, Bister, K, Beckerle, M (1995): The Cysteinerich Protein Family of Highly Related LIM Domain Proteins. J Biol Chem 270(48), 28946-28954

Wilding, J, Lygate, C, Davies, K, Neubauer, S, Clarke, K (2005): MLP accumulation and remodelling in the infarcted rat heart. European Journal of Heart Failure $\underline{8(4), 343-346}$

Zheng, B, Han, M, Wen, J, Zhang, R (2008): Human heart LIM protein activates atrial-natriuretic-factor gene expression by interacting with the cardiacrestricted transcription factor Nkx2.5. Biochem $\mathrm{J} \underline{\text { 409(683-690 }}$

Zheng, Q und Zhao, Y (2007): The diverse biofunctions of LIM domain proteins: determined by subcellular localization and protein-protein interaction. Biol Cell 99(9), 489-502

Zolk, O, Caroni P, Bohm M (2000): Decreased Expression of the Cardiac LIM Domain Protein MLP in Chronic Human Heart Failure. Circulation 101(23), $\underline{\text { 2674-2677 }}$ 


\section{Danksagung:}

Allen voran danke ich Herrn Prof. Dr. med. G. Hasenfuß für die Unterstützung bei der Durchführung dieser Doktorarbeit, die ich freundlicherweise unter dem angegebenen Thema bearbeiten konnte.

Herrn Dr. B. Unsöld danke ich für seine umfassende Betreuung und Beratung, Anleitung zum wissenschaftlichen Arbeiten und Einführung in zahlreiche Methoden sowie auch für seine Begeisterung für die Wissenschaft und die Motivation, die ich durch unsere Diskussionen immer wieder erhalten habe.

Herrn Dr. T. Seidler danke ich insbesondere für die Erstellung des Konstruktes des nlsMLP-Virus, welches eine Grundlage dieser Arbeit darstellt, und die Beratung bei vielen methodischen Fragestellungen. C. Grebe und T.-M. Klingebiel danke ich für viel praktische Hilfe bei der Durchführung der Experimente. Ebenso möchte ich Dr. K. Nguyen und Ihren Mitarbeitern und Mitarbeiterinnen für Ihre praktische und beratende Hilfe danken.

Ihnen allen und den hier nicht namentlich genannten Mitarbeiterinnen und Mitarbeitern, sowie Doktorandinnen und Doktoranden des Labors von Prof. Dr. med. G. Hasenfuß an der Universitätsklinik Göttingen gilt mein Dank für alle Unterstützung und Hilfe, die ich bei der Durchführung dieser Arbeit erhalten habe. 


\section{Lebenslauf:}

Ich wurde geboren am 10.04.1983 in Hannover. Meine Eltern sind Prof. Dr. Hartwig Donner und Dr. Irmhild Donner-Widdel, meine Geschwister sind Annina Donner (geboren 1987) und Leonard Donner (geboren 1987). Meine Schulbildung fand statt von 1989-1993 an der Kästnerschule Hannover und von 1993-1994 an der Orientierungsstufe Lüerstraße in Hannover, sowie von 19941995 an der Orientierungsstufe Stadtmitte in Lüneburg. In Lüneburg habe ich anschließend das Wilhelm-Raabe-Gymnasium von 1995-2002 besucht mit Abschluss des Abiturs. Ab September 2002 habe ich meine Studium der Humanmedizin an der Georg-August-Universität Göttingen begonnen. 2004 habe ich das Physikum abgelegt. Während der klinischen Ausbildung habe ich 2006/2007 ein Freisemester für den experimentellen Teil meiner Doktorarbeit in der Kardiologie genommen. Ebenfalls habe ich meine klinische Ausbildung in Göttingen für ein Ambassadorial Scholarship der Rotary Foundation unterbrochen, in dessen Rahmen ich 2007 für 9 Monate in Pretoria (Südafrika) an der Pretoria University gearbeitet habe. Im November 2009 konnte ich mein Studium an der Universität mit Abschluss des zweiten Teils der Ärztlichen Prüfung beenden. 